\title{
THE IMPORTANCE OF CREDIT FOR MACROECONOMIC ACTIVITY: IDENTIFICATION THROUGH HETEROGENEITY
}

\author{
Simon G. Gilchrist and Egon Zakrajšek*
}

Recent work in macroeconomics emphasizes the role of credit in the transmission mechanism for monetary policy and as a propagation mechanism of business cycle shocks. ${ }^{1}$ While much evidence has been gathered, not all researchers agree on the relevance of credit for the transmission of monetary policy or as a propagation mechanism of business cycle shocks. For the most part, every one agrees on the facts at hand but differs on their interpretation. In short, the argument is over identification. The primary purposes of this paper are to clarify the identification issues involved; to highlight those identification schemes that are promising avenues for measuring the importance of credit in aggregate fluctuations; and to discuss both previous and new evidence in light of the identification schemes proposed.

The role of credit in the monetary transmission mechanism can be divided into two separate phenomena. The first has been dubbed the "credit channel" of monetary policy. The second has been called the "financial accelerator." Both rely on credit frictions that are absent in the standard neoclassical models that economists typically use to explain business cycle fluctuations. Both, however, are complementary to the standard "money channel" described in textbook treatments of monetary transmission. As such, they provide an additional rather than a competing mechanism for the propagation of monetary policy shocks.

*Assistant Professor of Economics, Boston University, and Economist, Federal Reserve Bank of New York, respectively. The authors thank Mark Gertler for valuable comments and the Center for Economic Studies staff at the U.S. Bureau of the Census for providing the firm-level QFR data. The second author thanks the Federal Reserve Board for their gracious hospitality during the project.

1 See Gertler (1988) and Bernanke (1993) for exhaustive reviews of the literature. 
The credit channel emphasizes the importance of bank lending in the monetary transmission mechanism. The existence of the credit channel presumes that capital markets are imperfect, owing to information asymmetries between borrowers and lenders. As a consequence, some borrowers are unable to borrow on the open market without paying large premiums on external finance. Banks specialize in information-intensive loans and are able to reduce the premium for bankdependent borrowers. Monetary policy has real consequences because of its effect on banks' ability to lend. Open market operations lead to a contraction in reserves and a decrease in funds available for lending. As long as banks face imperfections in issuing certificates of deposit (CDs) to offset the contraction in reserves, bank lending must fall. Bank-dependent borrowers, consequently, are forced to seek funds at a much higher cost on the open market-to the extent they are able to obtain funds at all. As a result, spending by bank-dependent borrowers contracts.

The financial accelerator emphasizes the importance of balance sheet conditions in propagating shocks to the economy. As with the credit channel, the existence of the financial accelerator depends on the assumption that capital markets are imperfect, and that external and internal finance are not perfect substitutes. The crucial point for the financial accelerator is that the size of the premium on external funds depends on the firm's balance sheet condition. As balance sheets deteriorate following a contractionary monetary policy-regardless of whether the initial effect comes through interest rates or the initial decline in spending by bank-dependent borrowers-premiums on external finance rise, exacerbating the overall decline in spending.

Because the financial accelerator relies only on the assumption of credit market frictions and not on the additional assumption that a contraction in reserves limits banks' ability to lend, it is both a broader phenomenon than the credit channel and a necessary condition for the existence of the credit channel. Thus, evidence in favor of the financial accelerator is crucial for proving the existence of the credit channel, while the converse is not true.

All convincing evidence in favor of either a credit channel or the financial accelerator comes from studies that focus on the differential behavior of agents. This is the premise of our paper. The focus on differential behavior is important for two reasons. First, models that incorporate financial frictions are more relevant for certain types of agents, certain classes of borrowers, and certain sectors of the economy. The propagation mechanisms generated by these models are more relevant at certain points in the business cycle, namely, when cash flows are dropping and balance sheets are deteriorating. Second, because of the difficulties associated with formulating and estimating true structural models, empirical exercises seeking to establish the validity of 
either a credit channel or a financial accelerator must make comparisons against benchmarks where such credit effects are less likely to be relevant. By observing and measuring the differential behavior of economic agents under consideration, one can potentially attribute some, if not all, of the difference in behavior to frictions caused by credit markets. We elaborate on this premise in the next section. We then turn to a discussion of the existing evidence and provide some new evidence on the relevance of credit for monetary policy and macroeconomic fluctuations.

To limit the scope of the discussion, we address only firm behavior, although all of the identification issues apply equally well to consumers; see Attanasio (1994) for a recent discussion of credit issues on the consumer side. To further limit the scope of the paper, we center the discussion around evidence generated from one data set: the U.S. Bureau of the Census's Quarterly Financial Report for Manufacturing, Mining and Trade Corporations (QFR). Thus, a secondary purpose of this paper is to provide a progress report on research using the QFR data. Because it is available at high frequency and at various levels of aggregation, the QFR data set is uniquely suited for analyzing credit issues and how they relate to macroeconomics. As will be discussed below, the QFR data have already provided valuable insights into the identification issues raised by credit market imperfections. In addition, the QFR data have provided substantial evidence in favor of a credit mechanism, especially through the financial accelerator described above.

\section{IDENTIFICATION THROUGH HETEROGENEITY}

To understand the essential role that heterogeneity plays in any identification scheme used to measure the importance of credit in the economy, it is useful to review briefly the theoretical underpinnings that motivate the existence of a premium on external funds, and how such a premium would respond to changes in interest rates and aggregate demand conditions. We then turn to a discussion of financial intermediaries and the role of monetary policy.

As a starting point, consider the implications of neoclassical investment theory. According to this theory, firms make investment decisions to maximize the net present value of profits. If interest rates rise, the net present value of profits falls, making investment less attractive. If expected future profits fall, net present value also falls, once again leading to a drop in investment spending. It is important to note that the firm's investment decision depends entirely on the future returns of the specific project under consideration and not on the current or past financial position of the firm. If the firm must borrow to complete or undertake the investment project, creditors are willing to lend the necessary funds at the current open-market interest rate. Thus, we have 
the celebrated Modigliani-Miller (1958) result that real and financial decisions of the firm are completely separable.

In the presence of capital market imperfections, the separation of real and financial decisions no longer occurs. Balance sheet conditions affect the firm's ability to borrow at current interest rates. The theoretical motivation for this link can be found in the vast literature on asymmetric information and moral hazard in credit markets. An important insight from this literature is that such credit market imperfections create a wedge between the costs of external and internal finance. This wedge exists to compensate lenders for the risk that a borrower may either ex ante misrepresent the value of a given investment project or ex post behave in a manner that expropriates value from the lender. To mitigate such risk, the lender must monitor the borrower, incurring costs in the process.

In general, the premium on external funds will be highest where information asymmetries are the most severe and where the risk of opportunistic behavior is hardest to mitigate. Thus, small firms with idiosyncratic projects that are more difficult to value than those of large firms will face higher premiums. Younger firms with returns less known to the market will face higher premiums. By the same token, firms with projects backed by collateral will face lower premiums. More generally, the lower the collateralizable net worth of the firm, the greater the premium on external funds.

An example of such a situation is displayed in Figure 1.2 The $d d$ line represents the demand for funds by the firm. It is a downward-sloping function of the cost of funds. The ss line represents the supply of funds. Up to the point $W$ (the firm's net worth), lenders face very little risk of opportunistic behavior and are willing to lend at the open market interest rate. Beyond $W$, however, lenders charge a premium over the open-market rate to compensate for the increased probability of opportunistic behavior on the part of borrowers. Because of the premium on external funds, the supply of funds curve for the individual firm is upward-sloping, leading to an investment level $I^{*}$, below the perfect markets level $I^{P}$.

While the under-investment result is interesting in its own right, what matters for understanding the effects of monetary policy shocks is how the premium on external funds varies with both the state of aggregate demand and the risk-free interest rate. We consider both in turn. Figure $1 \mathrm{~A}$ shows the effects of a rise in demand. In the perfect

2 This example is based on the costly state verification (CSV) model presented in Gertler and Gilchrist (1991). Early examples of CSV models are Townsend (1979), Gale and Hellwig (1985), and Williamson (1987). Additional models that incorporate financial frictions in various guises include Jensen and Meckling (1976), Jaffe and Russell (1976), Leland and Pyle (1977), Stiglitz and Weiss (1981), and Myers and Majluf (1984). 


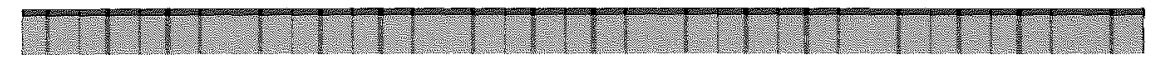

Figure 1

\section{The Premium for External Funds}
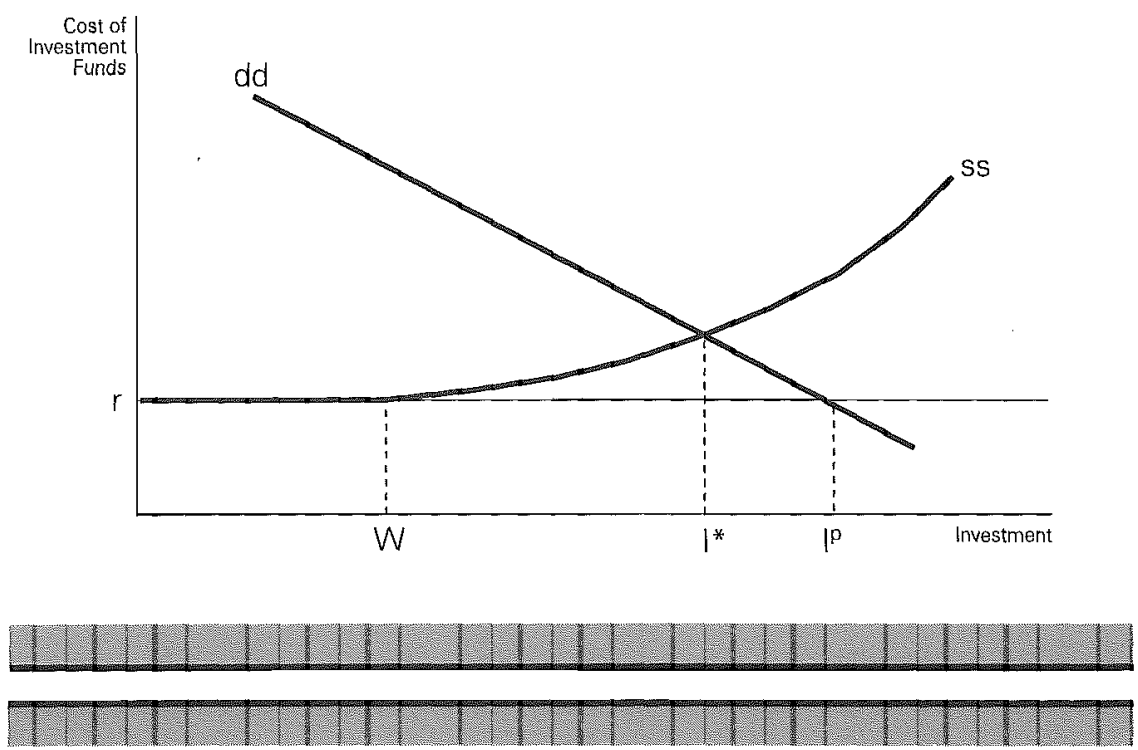

Figure 1A

\section{The Premium for External Funds}

IMPACT OF A RISE IN DEMAND
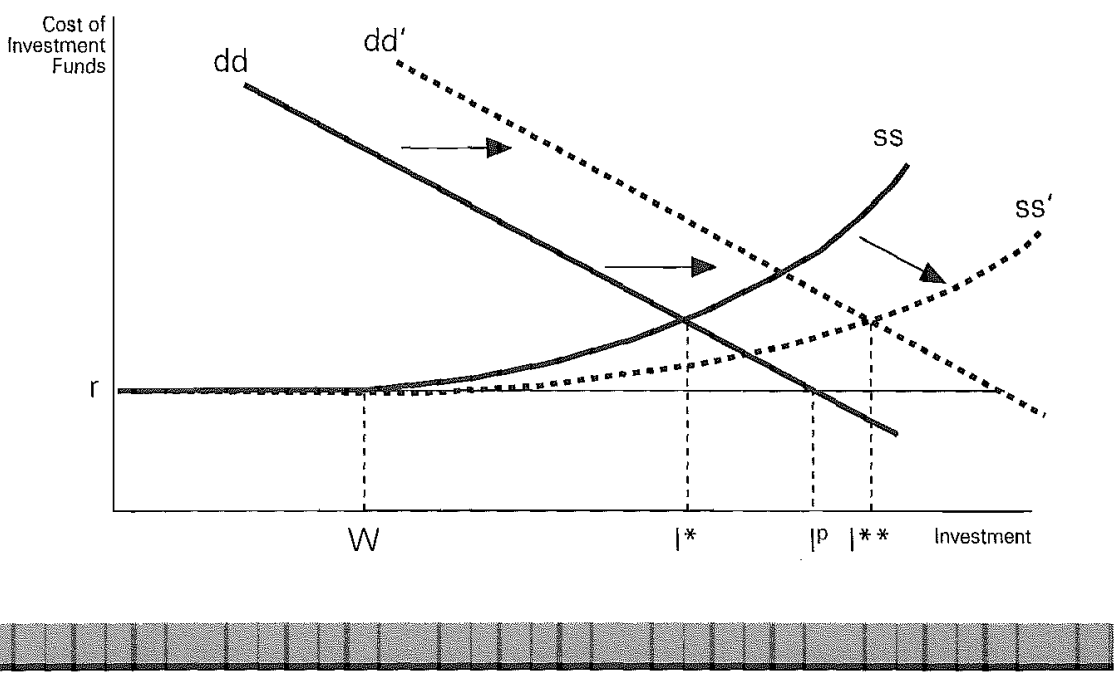


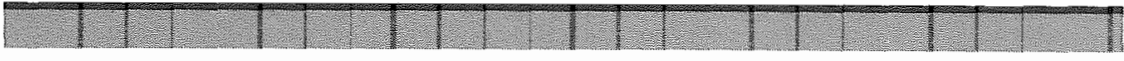

Figure 1B

\section{The Premium for External Funds} A Rise In THE RISKless INTERESt RATE
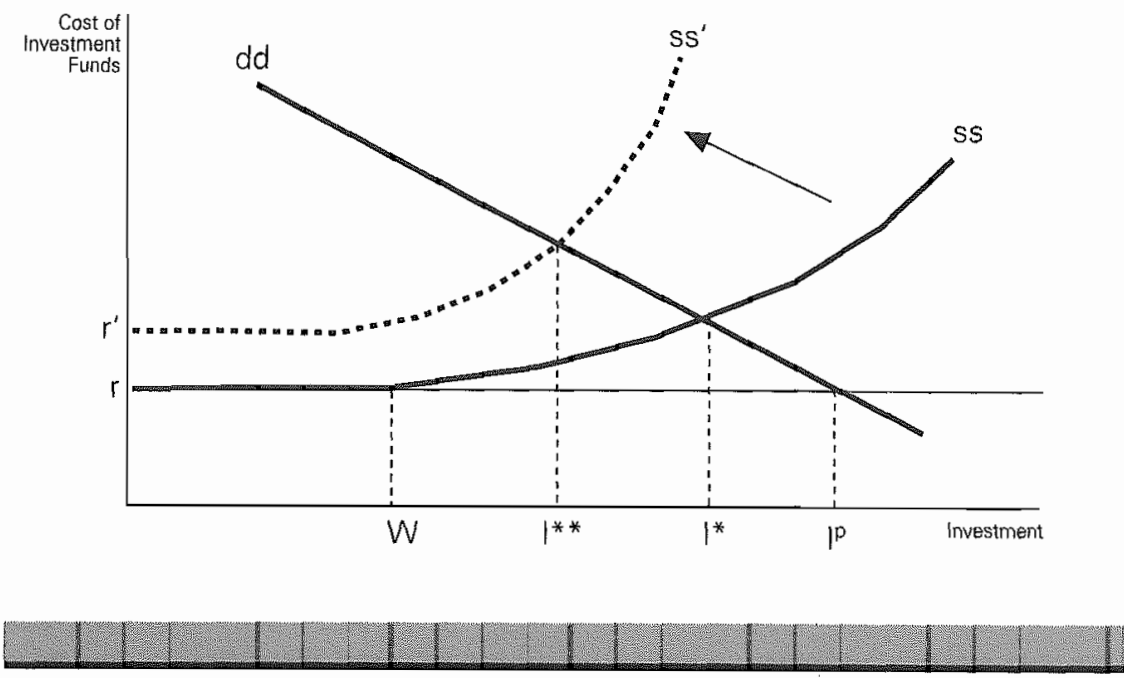

markets case, as demand increases, expected future profits rise, making firms more willing to invest. This shifts out the demand curve to $d d^{\prime}$ and raises investment spending for a given cost of funds. The credit market frictions amplify this effect. At higher profit levels, net worth has increased for a given project size, and the benefits of reneging on contractual obligations are lower. Borrowers are less likely to default, and lenders need not monitor as often. With less monitoring, the required premium on external funds falls (a rightward shift in the ss curve), and the effect of the demand shock on investment spending is magnified.

A rise in risk-free rates has a similar magnification effect, as shown in Figure 1B. At higher interest rates, default probabilities rise, causing lenders to increase the premium on external funds. An increase in the premium puts firms at even greater risk of default. This leads to an increase in the required premium that is much larger than the rise in the open-market interest rate. Once again, the initial shock is magnified through its effect on the premium for external funds.

The connection between the financial accelerator and the credit channel is easily understood, once one recognizes the special role that banks play in the credit intermediation process. Given the high cost of 
obtaining information for certain classes of borrowers, it is natural to expect certain institutions to specialize in information-gathering activities. Traditionally, banks have performed this role, in part because of the information advantage they obtain through observing would-be-borrowers' deposit flows. ${ }^{3}$ Over time, institutions such as banks develop knowledge specific to their class of borrowers in general and to their own customers in particular. By reducing the information asymmetry, financial intermediaries can lower the premium on external funds. Because such knowledge is difficult to convey to third-party lenders, disruptions in the supply of credit available through these intermediaries can have immediate and large consequences on spending. ${ }^{4}$ With traditional borrowing relationships destroyed, many bank-dependent firms and consumers will be forced into the market, where they face stiff premiums on external funds. At the prevailing rates, many may simply forgo planned investment projects, leading to large sudden drops in spending by certain classes of borrowers.

The link between theory and empirical work is established by determining factors that are likely to influence the size of the premium on external finance, the degree of the magnification effects, and the extent to which a firm must rely on bank loans rather than some other form of finance less subject to supply shocks through open market operations. Both the size of the premium on external finance and the degree to which a firm is tied to the bank loan market rather than other forms of external finance are heavily influenced by the firm's size, age and previous financial track record. Industry-specific characteristics such as the riskiness of projects, the degree to which investments are collateralizable, and the difficulty associated with evaluating borrowers' claims are also likely to be important determinants of the premium on external funds. By comparing the behavior of firms with such characteristics relative to the behavior of firms that have little difficulty obtaining funds at the open-market rate, we can test for the presence of financial frictions and measure the extent to which these frictions distort firm hiring and investment patterns.

${ }^{3}$ Fama (1980) outlines the special role of banks; Himmelberg and Morgan (1995) provide a more recent discussion.

${ }^{4}$ A central issue in the literature, of course, is the link between monetary policy and credit supply disruptions. According to the traditional credit view, contractions in monetary policy drain reserves from the system and force a contraction on both the asset and the liability sides of the balance sheet. As long as banks do not face a perfectly elastic supply-of-funds schedule in the $\mathrm{CD}$ market, monetary policy contractions reduce the supply of bank loans. Romer and Romer (1990) forcefully argue against any such link between reserve contractions and loan supply, owing to the ability of banks to issue certificates of deposit not subject to reserve requirements. Kashyap and Stein (1994), on the other hand, argue in favor of such a link; see Bernanke and Gertler (1995) for a recent discussion of the issues and the evidence. 
For the magnification effect, a key determinant of the premium on external funds is $W$-the net worth of the firm, or the level of unencumbered assets or future earnings available as collateral for new investment projects. Given the complexity of present day financial contracts, it is difficult to quantify such a concept precisely. Nonetheless, some basic indicators of financial health commonly used by market analysts seem informative. Firms with high leverage ratios are likely to face greater difficulties obtaining new funds on the market, as are firms with low coverage ratios-that is, firms with a high level of current interest payments relative to their earnings. By using disaggregated data to compare the behavior of firms in different financial positions, we can potentially measure the distortions created by financial frictions.

In addition to being useful indicators of firms with imperfect access to credit markets, both of these variables are intuitively appealing in understanding the asymmetric nature of the financial accelerator discussed above. In good times, as profits increase and firms become flush with cash, borrowers have little trouble financing new investment projects and making existing debt payments. Under such conditions, a shock to earnings or interest rates will have very little magnification effect through the premium on external funds. As the economy turns down and balance sheet positions are weakened, however, a greater number of firms find themselves saddled with large debt, high interest payments, and low cash flow. In such precarious financial positions, these firms will face high premiums on external funds, either through direct price effects, credit rationing, or more severe non-price contract terms such as restrictive debt covenants. With only aggregate time series, however, one cannot identify the extent to which firms are moving from one class to another and, therefore, how important a credit mechanism is in creating business cycle asymmetries.

The identification strategy of comparing one class of firms to another in order to measure the extent and importance of financial frictions takes advantage of the inherent heterogeneity underlying most aggregate time series data. In addition, it emphasizes the limitations of models that focus on representative agents. The limitation of representative agent models does not come from our inability to formulate representative agent models with important credit frictions. ${ }^{5}$ Rather, the limitation comes from our inability to distinguish such models from business cycle models with alternative propagation mechanisms that do not rely on credit frictions. Only by relying on the fact that some firms, at least some of the time, do not face the adverse consequences associated with limited access to credit markets, can we identify how other firms, at other times, are seriously affected by such restricted access.

5 Bernanke and Gertler (1989) present one example of such models. 


\section{Evidence from Financial Data}

We now turn to a discussion of identification through the use of financial data, focusing on the comparison between aggregate lending data and disaggregated lending data. We argue that only disaggregated lending data can provide convincing evidence of the presence of either a credit channel or the financial accelerator. We also wish to emphasize that evidence from lending data alone is not sufficient to establish the relevance of credit frictions in propagating and amplifying business cycle shocks. Also needed is supporting evidence from nonfinancial data. This is discussed in the next section.

\section{Interpreting the Existing Evidence}

Prominent studies that attempt to gauge the importance of credit in the macroeconomy have focused on the following criterion: To what extent do movements in aggregate credit or aggregate bank loans either explain or lead movements in real variables? Both King (1986) and Ramey (1993) show that total bank lending has no marginal forecasting power for either industrial production or other macro real variables. Romer and Romer (1990) show that monetary aggregates fall immediately following a shift to tight monetary policy and nine months prior to the ensuing drop in output, whereas bank loans fall only coincidently with the resulting decline in output. These results are taken by the authors as strong evidence against a credit channel for monetary policy and, at least in King's case, as strong evidence against credit mattering at all for the transmission of monetary policy shocks. ${ }^{6}$

As Bernanke and Blinder (1992), Gertler and Gilchrist (1993), and Bernanke, Gertler, and Gilchrist (1994) all emphasize, however, such empirical exercises do not provide information on either the relevance of a credit channel for monetary policy or the presence of a financial accelerator. First, banks liquidate securities rather than contract loan volume immediately following a tightening of monetary policy. Banks do so in part to offset the effects that tight money will have on their ability to lend to valued customers. Thus, the fact that bank loans only fall with a nine-month lag rather than immediately following a switch to tight monetary policy provides no information about banks' ability to obtain funds through $C D$ issuance and, consequently, cannot be considered as a relevant test for the existence of a credit channel.

Second, the notion that bank lending should have marginal predictive power, once one controls for monetary policy through either a

6 Both Ramey (1993) and Romer and Romer (1990) are careful to point out, however, that their findings do not provide evidence against the importance of a broader credit mechanism such as the financial accelerator. 
monetary aggregate or an interest rate instrument such as the federal funds rate, assumes that credit disruptions provide an important independent source of shocks. According to the general equilibrium theories linking balance sheet conditions to real activity, however, no such shocks need exist. ${ }^{7}$ The financial accelerator is an amplification device, not an independent source of variation. Although disruptions to credit supply-through independent shocks to bank lending such as changes in regulatory policy, for example-may have large effects, such shocks need not be empirically important for credit to matter in conditioning the economy's overall response to either changes in monetary policy or other sources of variation.

Finally, once it is recognized that the effects of credit frictions on debt quantities are most likely identified through the differential behavior of certain classes of borrowers, the relevance of any exercise that focuses only on aggregate lending patterns must be questioned. Kashyap, Stein, and Wilcox (1993) (KSW hereafter) were the first to make this point empirically. They argued that a credit channel for monetary policy could be identified more readily through the differential behavior of bank loans relative to commercial paper movements than by looking only at total lending. According to KSW, bank loans would shrink following tight money, whereas commercial paper would expand, in part because customers shut out of the bank loan market would naturally turn to commercial paper.

The evidence presented by KSW supports this contention. Bank loans drop relative to commercial paper following tight money, though the mechanism is not quite what KSW described. Using even more disaggregated data for the manufacturing sector, both Oliner and Rudebusch (1992) and Gertler and Gilchrist (1993) show that movements in the aggregate mix between commercial paper and bank loans are not driven by bank versus nonbank lending but by small-firm versus large-firm borrowing. In particular, following tight money, all types of borrowing by small firms fall, whereas borrowing by large firms actually expands in the first few quarters following a monetary contraction.

The expansion of credit to large firms following tight money is not often recognized and is worth emphasizing in the context of identifying the effects of monetary policy shocks through aggregate lending behavior. As Gertler and Gilchrist (1993) point out, many firms have a strong countercyclical demand for short-term credit, as inventories rise and cash flows fall in the first few quarters following a tightening of monetary policy or at a business cycle turning point. If funds were

7 Examples of dynamic general equilibrium models that incorporate a financial accelerator include Greenwald and Stiglitz (1993), Bernanke and Gertler (1989, 1990), Calomiris and Hubbard (1990), Gertler (1992), and Kiyotaki and Moore (1993). 
available at prevailing open-market rates, all firms would increase their borrowing to smooth the effect of declining cash flows. Only those firms with relatively unimpeded access to credit, however, are able to obtain the desired funds. Thus, following a shift to tight money, "high-quality" firms with access to the commercial paper market expand their credit (Calomiris, Himmelberg, and Wachtel 1995); firms with bank commitments draw down their lines of credit (Morgan 1994); and the "highquality" bank customers receive the funds obtained through the banking system's liquidation of securities (Lang and Nakamura 1995). Those left out in the cold are the smaller, riskier, less-valued bank customers, which, once shut out of the bank loan market, have no recourse but to curtail operations, liquidate inventories, cut investment spending, and reduce their work force. Their reductions in spending further exacerbate the downturn, leading to an even greater contraction than before.

Once the countercyclical demand for credit generated by an adverse shock to monetary policy is recognized, it becomes immediately obvious that important credit frictions may be at work with very little observable effect on aggregate credit quantities, especially over the first few quarters following a switch to tight monetary policy. If this were the case, we would not necessarily expect any observable relationship between aggregate credit movements and future output movements. We would expect, however, an observable relationship between the differential borrowing rates of high-quality versus low-quality borrowers and future output movements, especially in a framework that does not control for the original source of the shock. In addition, we would expect monetary policy to have a strong effect on the relative borrowing patterns of these two types of firms.

\section{Some New Evidence from Financial Data}

In this section, we test the proposition that the borrowing rates of "low-quality" firms relative to those of "high-quality" firms have predictive power for aggregate real variables. We also test the proposition that differential movements in such borrowing rates are influenced by monetary policy. To obtain a debt measure for "low-quality" and "high-quality" firms, we follow Gertler and Gilchrist (1993) and use the ratio of short-term debt of small manufacturing firms relative to shortterm debt of all manufacturing firms, constructed from the published QFR data. We call this ratio the small/all mix. ${ }^{8}$ We view the first test as

${ }^{8}$ Other lending variables that reflect potential differences in borrower quality are available, though generally not for as long a time period. In addition, the QFR data are disaggregated by size as well as by type of debt (for example, bank vs. nonbank, commercial paper, and so on). The data are therefore well-suited for making additional 
complementary to Ramey (1993), who uses the QFR data to examine the predictive power of short-term debt issued by small firms relative to that of large firms for aggregate industrial production. We view the second test as complementary to the evidence presented in Gertler and Gilchrist (1993), who characterize the behavior of small-firm and large-firm borrowing in response to monetary policy shocks, using impulse response functions. In addition, both tests complement the analysis of small-firm versus large-firm borrowing patterns provided by Oliner and Rudebusch (1992).

We test the first proposition by examining the predictive power of the small/all mix for the following measures of aggregate economic activity: real GNP, manufacturing industrial production, manufacturing inventories, and manufacturing employment. 9 We also examine the predictive power of the small- and large-firm debt series separately, as well as the relative behavior of bank and nonbank debt for small and large firms. Table 1 reports the results of these exercises in the context of a bivariate VAR system. The top panel reports probability values from the exclusion tests for each debt variable across the various measures of real economic activity. ${ }^{10}$ The bottom panel reports the t-statistics for the sums of coefficients on the debt variables and, thus, provides an indication of the sign of the effect that each debt variable has on real activity.

The bivariate results provide strong support for the hypothesis that credit flows between small and large firms predict real economic activity. The probability values from the exclusion test for the small/all mix are less than 0.01 in three out of the four cases. In addition, the $t$-statistics on the sums of coefficients indicate that an increase in the small/all debt ratio leads to a highly significant increase in the growth rates of GNP, manufacturing industrial production, and manufacturing employment, as one would expect. The effect on inventories is ambiguous and probably reflects the dynamics associated with unexpected inventory buildup following a slowdown in economic activity.

Separating these variables by small firms versus large firms and

\footnotetext{
comparisons of bank vs. nonbank debt. We focus on short-term rather than long-term debt to avoid the measurement problems associated with disentangling stocks and flows when only stocks are observable. As Gertler and Gilchrist (1993) show, the overall conclusions regarding disaggregated debt movements do not depend on the use of short-term rather than long-term credit quantities. In addition, Oliner and Rudebusch (1992) provide similar evidence based on total debt.

${ }^{9}$ We focus on the manufacturing variables since the lending data are constructed using manufacturing firms only. Ramey (1993) provides a similar test of predictive power for aggregate industrial production alone, although she uses the ratio of small- to large-firm borrowing rather than small- to all-firm borrowing. Since these variables are simple transformations of each other, it makes very little difference which one is used.

${ }_{10}$ We start the estimation in 1975: QI to allow for the fact that credit conditions may have changed following the regulatory change that allowed banks to issue large time deposits without being subject to reserve requirements.
} 
Table 1

Short-Term Debt and Aggregate Economic Activity: Results from a Bivariate VAR System

p-values from Exclusion Tests on Debt Variables

\begin{tabular}{|c|c|c|c|c|}
\hline \multirow[b]{3}{*}{ Debt Variable } & \multicolumn{4}{|c|}{ Dependent Variable } \\
\hline & \multirow[b]{2}{*}{$\begin{array}{l}\text { Real } \\
\text { GNP }\end{array}$} & \multicolumn{3}{|c|}{ Manufacturing } \\
\hline & & $\begin{array}{l}\text { Indust. } \\
\text { Prod. }\end{array}$ & Inventories & Employment \\
\hline Manufacturing Mix $^{a}$ & .04 & .01 & .08 & .07 \\
\hline Large Firm Mix & .76 & .32 & .79 & .56 \\
\hline Small/All Mix ${ }^{c}$ & .00 & .00 & .07 & .00 \\
\hline \multicolumn{5}{|l|}{ Small Firm } \\
\hline Short-Term Bank Debt & .84 & .28 & .74 & .62 \\
\hline Short-Term Nonbank Debt & .80 & .19 & .82 & .47 \\
\hline \multicolumn{5}{|l|}{ Large Firm } \\
\hline Short-Term Bank Debt & .02 & .00 & .05 & .02 \\
\hline Short-Term Nonbank Debt & .01 & .00 & .07 & .01 \\
\hline
\end{tabular}

t-statistics on Sums of Coefficients for Debt Variables

\begin{tabular}{|c|c|c|c|c|}
\hline \multirow[b]{3}{*}{ Debt Variable } & \multicolumn{4}{|c|}{ Dependent Variable } \\
\hline & \multirow[b]{2}{*}{$\begin{array}{l}\text { Real } \\
\text { GNP }\end{array}$} & \multicolumn{3}{|c|}{ Manufacturing } \\
\hline & & $\begin{array}{l}\text { Indust. } \\
\text { Prod. }\end{array}$ & Inventories & Employment \\
\hline Manufacturing $\mathrm{Mix}^{\mathrm{a}}$ & 2.75 & 2.60 & 1.75 & 2.11 \\
\hline Large Firm Mix & .73 & .73 & .30 & .42 \\
\hline Small/All Mix ${ }^{\mathrm{C}}$ & 4.31 & 3.87 & 1.37 & 3.34 \\
\hline \multicolumn{5}{|l|}{ Small Firm } \\
\hline Short-Term Bank Debt & -.12 & -1.06 & .29 & -.11 \\
\hline Short-Term Nonbank Debt & -.09 & -1.05 & .41 & -.07 \\
\hline \multicolumn{5}{|l|}{ Large Firm } \\
\hline Short-Term Bank Debt & -3.17 & -3.96 & -1.08 & -3.37 \\
\hline Short-Term Nonbank Debt & -3.52 & -4.35 & -.83 & -3.52 \\
\hline \multicolumn{5}{|c|}{$\begin{array}{l}\text { Notes: The bivariate system includes four lags of the growth rate of the dependent variable and four lags } \\
\text { ui the growth rate of the debt variable. Sample range: } 1975 \text { : Ql to } 1991: \text { QIV. }\end{array}$} \\
\hline \multicolumn{5}{|c|}{$\begin{array}{l}\text { a Ratio of short-term bank loans to commercial paper plus short-term bank loans, for all manufacturing } \\
\text { firms. }\end{array}$} \\
\hline \multicolumn{5}{|c|}{$\begin{array}{l}\text { batio of short-term bank loans to commercial paper plus short-term bank loans, for firms above the } 30 \text { th } \\
\text { percentile in sales. }\end{array}$} \\
\hline
\end{tabular}

bank versus nonbank debt indicates a number of interesting patterns. First, differences in the predictive power of debt variables arise through differences in class of borrower and not through differences in class of debt. Thus, bank debt and nonbank debt behave in a similar manner, but small-firm versus large-firm debt does not. In particular, for large 
firms, increases in either bank or nonbank debt predict declines in real economic activity, while for small firms the opposite occurs. Although the similarity in predictive power of bank versus nonbank debt provides potential evidence against a "direct credit channel" for monetary policy, it is important to be cautious with this interpretation. As argued above, we would expect banks to continue to make loans to their larger, more valued customers as they sell off securities. In addition, for small firms, the nonbank category is very small and is not as reliable an indicator of credit behavior. ${ }^{11}$

Second, the t-statistics and p-values for exclusion tests of the first three lending variables confirm that the predictive power of the mix between bank loans and commercial paper for manufacturing comes entirely through the ratio of small-firm borrowing relative to total borrowing (that is, the small/all mix) and not through differential movements between bank loans and commercial paper by firms with potential access to both markets. ${ }^{12}$ This finding further supports the evidence presented in Oliner and Rudebusch (1992), Gertler and Gilchrist (1993), and Calomiris, Himmelberg, and Wachtel (1995) that differential movements between bank loans and commercial paper reflect differential movements in debt by type of borrower and not by type of debt.

Finally, it is worth noting that much of the predictive power of the small/all mix can be captured by looking only at large-firm behavior in the bivariate regressions. When these regressions are augmented to include other variables such as the federal funds rate and inflation, as in Table 2, the predictive power of large-firm debt variables vanishes, while the small/all mix still retains significant predictive power for the growth rates of GNP, manufacturing inventories, and manufacturing employment. Overall, we find that the ratio of small-firm borrowing relative to total borrowing has both the predictive power and sign one would expect based on credit theories.

The second prediction to be tested is whether monetary policy has any effect on the borrowing patterns of small and large firms. To test this hypothesis, each debt variable is regressed on four lags of itself and four lags of the federal funds rate. We also consider a multivariate specification that includes the growth rate of industrial production for the manufacturing sector. The probability values from exclusion tests and

${ }^{11}$ It is also possible that some firms are pushed out of the commercial paper market into the bank loan market as their credit quality deteriorates. Such an effect would mute any differential response for large firms.

12 Gertler and Gilchrist (1994) show that manufacturing firms with total assets of less than $\$ 250$ million have virtually no commercial paper outstanding. In addition, 90 percent of manufacturing commercial paper is issued by firms with total assets greater than $\$ 1$ billion. 
Table 2

Short-Term Debt and Aggregate Economic Activity: Results from a Multivariate VAR System

p-values from Exclusion Tests on Debt Variables

\begin{tabular}{|c|c|c|c|c|}
\hline \multirow[b]{3}{*}{ Debt Variable } & \multicolumn{4}{|c|}{ Dependent Variable } \\
\hline & \multirow[b]{2}{*}{$\begin{array}{l}\text { Real } \\
\text { GNP }\end{array}$} & \multicolumn{3}{|c|}{ Manufacturing } \\
\hline & & $\begin{array}{l}\text { Indust } \\
\text { Prod. }\end{array}$ & Inventories & Employment \\
\hline Manufacturing Mix ${ }^{a}$ & .40 & .17 & .21 & .36 \\
\hline Large Firm Mix & .91 & .52 & 98 & .73 \\
\hline Small/All Mix ${ }^{c}$ & .05 & .13 & .02 & .06 \\
\hline \multicolumn{5}{|l|}{ Small Firm } \\
\hline Short-Term Bank Debt & .98 & .36 & .55 & .67 \\
\hline Short-Term Nonbank Debt & .95 & .35 & .77 & .65 \\
\hline \multicolumn{5}{|l|}{ Large Firm } \\
\hline Short-Term Bank Debt & .32 & .11 & .02 & .13 \\
\hline Short-Term Nonbank Debt & .28 & .11 & .06 & .11 \\
\hline
\end{tabular}

t-statistics on Sums of Coefficients for Debt Variables

\begin{tabular}{|c|c|c|c|c|}
\hline \multirow[b]{3}{*}{ Debt Variable } & \multicolumn{4}{|c|}{ Dependent Variable } \\
\hline & \multirow[b]{2}{*}{$\begin{array}{l}\text { Real } \\
\text { GNP }\end{array}$} & \multicolumn{3}{|c|}{ Manufacturing } \\
\hline & & $\begin{array}{l}\text { Indust. } \\
\text { Prod. }\end{array}$ & Inventories & Employment \\
\hline Manufacturing Mix $^{a}$ & 1.61 & 1.43 & 1.95 & 1.20 \\
\hline Large Firm Mix ${ }^{\mathrm{b}}$ & .15 & .11 & .16 & -.12 \\
\hline Small/All Mix & 2.69 & 2.27 & 2.59 & 2.31 \\
\hline \multicolumn{5}{|l|}{ Small Firm } \\
\hline Short-Term Bank Debt & .17 & -1.04 & .27 & -.38 \\
\hline Short-Term Nonbank Debt & .33 & -.91 & .43 & -.22 \\
\hline \multicolumn{5}{|l|}{ Large Firm } \\
\hline Short-Term Bank Debt & -1.85 & -2.70 & -1.97 & -2.49 \\
\hline Short-Term Nonbank Debt & -1.70 & -2.68 & -1.66 & -2.28 \\
\hline
\end{tabular}

Notes: The multivariate system includes four lags of the growth rate of the dependent variable, four lags of the growth rate of the debt variable, and four lags of the change in the federal funds rate. Sample range: $1975:$ QI to $1991:$ QIV.

a Ratio of short-term bank loans to commercial paper plus short-term bank loans for all manufacturing firms.

b Ratio of short-term bank loans to commercial paper plus short-term bank loans for firms above the 30th percentile in sales.

c Ratio of short-term debt for firms below the 30 th percentile in sales relative to short-term debt of all firms.

t-statistics for sums of coefficients on the federal funds rate are reported in Table 3. The results from both the exclusion tests and the tests of sums of coefficients provide strong support for the hypothesis that monetary policy significantly affects the differential growth rates of short-term debt between small and large firms. In particular, an increase 
Table 3

The Effect of the Federal Funds Rate on Short-Term Debt

\begin{tabular}{lrr}
\hline \multicolumn{1}{c}{ p-values from Exclusion Tests on the Federal Funds Rate } \\
\hline \multicolumn{1}{c}{ Debt Variable } & $\begin{array}{c}\text { Bivariate } \\
\text { System }^{\mathrm{a}}\end{array}$ & $\begin{array}{c}\text { Multivariate } \\
\text { System }^{\mathrm{b}}\end{array}$ \\
\hline Manufacturing Mix & .12 & .31 \\
Large Firm Mix & .12 & .95 \\
Small/Al! Mix & .82 & .06 \\
Small Firm & & \\
$\quad$ Short-Term Bank Debt & .00 & .13 \\
$\quad$ Short-Term Nonbank Debt & .02 & .13 \\
Large Firm & & .26 \\
$\quad$ Short-Term Bank Debt & .00 & .10 \\
$\quad$ Short-Term Nonbank Debt & .00 & \\
\hline
\end{tabular}

t-statistics on Sums of Coefficients of the Federal Funds Rate

\begin{tabular}{|c|c|c|}
\hline Debt Variable & $\begin{array}{l}\text { Bivariate } \\
\text { System }^{a}\end{array}$ & $\begin{array}{c}\text { Multivariate } \\
\text { System }^{\circ}\end{array}$ \\
\hline $\begin{array}{l}\text { Manufacturing Mix } \\
\text { Large Firm Mix } \\
\text { Small/All Mix }\end{array}$ & $\begin{array}{r}-2.35 \\
-.50 \\
-3.81\end{array}$ & $\begin{array}{r}-1.90 \\
-.69 \\
-2.70\end{array}$ \\
\hline $\begin{array}{l}\text { Small Firm } \\
\text { Short-Term Bank Debt } \\
\text { Short-Term Nonbank Debt }\end{array}$ & $\begin{array}{l}1.59 \\
1.53\end{array}$ & $\begin{array}{l}.05 \\
.14\end{array}$ \\
\hline $\begin{array}{l}\text { Large Firm } \\
\text { Short-Term Bank Debt } \\
\text { Short-Term Nonbank Debt }\end{array}$ & $\begin{array}{l}3.29 \\
3.61\end{array}$ & $\begin{array}{l}2.07 \\
2.44\end{array}$ \\
\hline
\end{tabular}

a The bivariate system includes four lags of the growth rate of the debt variable and four lags of the change in the federal funds rate.

$\mathrm{b}$ The mulivariate system includes four lags of the growth rate of the debt variable, four lags of the change in the federal funds rate, and four lags of the growth rate of manufacturing industrial production.

c Ratio of short-term bank loans to commercial paper plus short-term bank loans for all manufacturing firms.

d Ratio of short-term bank loans to commercial paper plus short-term bank loans for firms above the 30th percentile in sales.

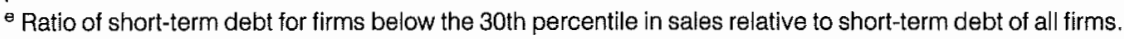

in the federal funds rate leads to a contraction of small-firm borrowing relative to large-firm borrowing.

In conclusion, the evidence from financial data disaggregated by size class in manufacturing confirms the fact that the differences in short-term borrowing behavior between small and large firms have substantial predictive power for real economic activity. In addition, the data are consistent with the view that monetary policy plays a crucial role in determining the pattern of such differences in borrowing behavior, in the direction suggested by credit-based propagation theories. 


\section{EVIDENCE FROM Nonfinancial DATA}

While consistent with a role for credit in the economy, the evidence using financial data alone cannot solve the identification problems posed by the literature. We must ask why funds flow from one class of borrower to another, and why such flows might have forecasting power for aggregate economic activity. One alternative explanation that does not rely on credit is that small, bank-dependent firms are subject to a different set of shock processes and adjustment mechanisms than large firms, or firms identified as having free access to credit markets. If, for example, small firms are on the fringes of the industrial process as suppliers or niche market producers, they may well be subject to more rapid and deeper contractions than their large-firm counterparts. If this were true, we might indeed expect the ratio of small- to all-firm borrowing to respond to monetary policy shocks and lead the business cycle, as the above evidence suggests.

Two approaches can be taken to solving the identification problem here. The first approach is to rely on additional time series evidence that is also consistent with a credit interpretation but much harder to explain with an alternative non-credit-related phenomenon. The other approach is to go directly to micro data and control for as many of the alternative shock and adjustment processes as possible, using both reduced-form and structural techniques. We discuss both in turn.

\section{Evidence from the Aggregate QFR Data}

To identify credit effects through time series data, one must have a data set that provides both a long time series dimension and enough heterogeneity to form a basis of comparison between agents with differential access to capital markets. By providing balance sheet and income statement data over the period from 1959:QI to 1991:QIV across different size classes of manufacturing firms, the QFR data are uniquely suited to the task. Using these data, Gertler and Gilchrist (1994) provide substantial evidence on the differential behavior of small versus large firms over the business cycle and in response to monetary policy shocks.

Regardless of the source of this differential behavior, the GertlerGilchrist evidence is striking. Following a shift to tight monetary policy, the contraction of small manufacturing firms-defined as firms in the bottom 30 th percentile of the sales distribution-is 2.5 times greater than that of large firms, over a 12-quarter horizon. This contraction can be seen across a wide variety of variables, but it is most noticeable in sales, inventories, and short-term borrowing. While one could potentially explain the differential response of sales with an alternative demand story, it is much harder to explain the differential response of the inventory/sales ratio and the debt/sales ratio with such a story. The 
evidence clearly suggests that large firms obtain additional funds to finance inventories as sales are declining, whereas small firms do not. In addition, Bernanke, Gertler, and Gilchrist (1994) show that controlling for industry-specific demand conditions does not substantially reduce the differential response of the inventory/sales ratio between small and large firms, as one would expect if a demand-based alternative were the true explanation.

Perhaps the most compelling evidence from a skeptic's point of view is the finding that spending by small firms is highly responsive to current credit conditions, even after controlling for the lagged dynamics normally associated with spending equations. Two pieces of evidence are relevant here. The first piece is the finding by Gertler and Gilchrist (1994) that inventory investment by small firms is highly responsive to a coverage variable that measures the ratio of income to short-term debt payments, whereas inventory investment by large firms is not. Thus, balance sheet conditions affect real decisions for small firms but not for large firms. This is true even after controlling for alternative sales processes and inventory adjustment speeds. A related piece of evidence is the finding by Oliner and Rudebusch (1994) that business fixed investment by small firms is highly responsive to cash flow shocks during recessionary periods. Such an asymmetric response arises naturally from a model with credit frictions but is much more difficult to reconcile with a model that assumes perfect capital markets.

\section{Evidence from the Firm-Level QFR Data}

While the time series evidence based on small versus large manufacturing firms paints a compelling picture of the process one would expect to observe if credit conditions play an important role in both the monetary transmission mechanism and business cycle fluctuations, the fact that the data are aggregated by size rather than by a more direct indicator of capital market access is a major limitation. Additional problems are posed by attempts to control for industry effects and other aggregation issues. Fortunately, the underlying firm-level data set that is used to construct the published QFR data aggregated by size class is available through the Center for Economic Studies at the U.S. Bureau of the Census for the period 1977:QI to 1991:QIII. Unlike Compustat or other firm-level data bases more commonly used in micro studies that seek to identify the effect of credit frictions on real behavior, the firm-level QFR data set is comprehensive for manufacturing, covering all corporations and not just publicly traded ones. ${ }^{13}$ The fact that the

${ }^{13}$ In fact, the firm-level QFR data form the only known U.S. data base that systematically provides either high-frequency or firm-level information about corporations 
data set is comprehensive implies that one can correctly aggregate results to obtain macroeconomic implications. The quarterly frequency of the data allows one to consider issues at a business cycle frequency. While work on this data base is preliminary, some interesting results have already emerged. We discuss these results again in the context of identifying the role of credit in the macroeconomy.

The principal identification problem posed at the micro level is, how does one separate a firm's response to a change in its financial position from its response to new profit opportunities? This identification problem can be easily understood in the context of standard firm-level investment regressions. As discussed above in the section "Identification through Heterogeneity," a positive shock to profits has two effects. First, to the extent that high profitability today signals high profitability tomorrow, firms will want to invest more. This is the standard neoclassical response. Second, higher profits today signal greater net worth and an improved financial position. The improved financial position lowers the premium on external funds and boosts the investment spending of constrained firms. In this manner, investment expenditures are more responsive to innovations in current earnings than the neoclassical model would suggest.

To test this hypothesis of "excess sensitivity" of investment to cash flow, past researchers regressed investment on Tobin's $Q$ and either current or past earnings. ${ }^{14}$ The identifying assumption of this approach is that Tobin's $Q$ adequately proxies for future profit opportunities through the forward-looking behavior captured by the stock market. ${ }^{15}$ To the extent that current or past earnings still had explanatory power for investment-even after controlling for future profit opportunities through Tobin's Q-they did so because of credit market frictions. This identification scheme, however, was called into serious doubt by researchers who found either little observable relationship between in-

that are not publicly traded. In addition, the firm-level QFR data provide information for the retail, wholesale, and mining sectors of the economy. Unlike the case of the manufacturing sector, the sampling of these sectors is not comprehensive; income and balance sheet statements are provided only for firms with assets above $\$ 50$ million; see Long and Ravencraft (1993) and Zakrajšek (1995) for detailed descriptions of the firm-level QFR data base.

14 The most influential paper in the literature is Fazzari, Hubbard, and Petersen (1988). Other examples include Devereux and Schiantarelli (1989), Hoshi, Kashyap, and Scharfstein (1991), Blundell, Bond, Devereux, and Schiantarelli (1992), Chirinko and Schaller (1993), Oliner and Rudebusch (1992), and Schaller (1993).

${ }^{15}$ Tobin's $Q$ is defined as the market value of the firm divided by the replacement value of its capital stock. The market value includes the stock market value of equity and the market value of debt outstanding. According to the $Q$ theory of investment, Tobin's $Q$ represents the shadow value of an additional dollar of investment. Thus, when $Q$ is greater than one, the value of an additional unit of investment inside the firm is greater than its replacement cost and the firm should invest more. 
vestment and $Q$ or implausibly high adjustment cost estimates (low $Q$ coefficients). These results suggest that Tobin's $Q$ is not an adequate proxy for future profit opportunities. Since, in principle, Tobin's $Q$ measures the present value of future earnings streams attributable to new investment, cash flow might help predict this stream, in which case one could not attribute the large, positive coefficient on cash flow solely to financial effects.

Gilchrist and Himmelberg (1994) (G-H hereafter) formalize this point by using a VAR forecasting framework to decompose the effect of cash flow on investment into two separate components-a component that forecasts future profitability under perfect capital markets, and a residual component that may be attributable to financial frictions. The results of their methodology provide the following insights for identification of credit effects. By relying on Tobin's $Q$ to control for future profit opportunities, rather than a VAR-based alternative that controls for predictive power of cash flow, one dramatically overstates the effect of cash flow on investment. This is especially true for firms classified as financially "unconstrained" and for which Tobin's $Q$ is a particularly bad proxy for future profit opportunities. Thus, without properly controlling for such profit opportunities, even large firms with commercial paper ratings appear overly responsive to cash flow shocks, relative to the perfect markets benchmark. Once one controls for the forecasting power of cash flow, however, all evidence of excess sensitivity disappears for "unconstrained" firms, and it is reduced for "constrained" firms.

The other lesson for the identification of credit effects provided by $\mathrm{G}-\mathrm{H}$ is that although the level of response of investment to cash flow effect differs substantially with and without controlling for the forecasting component, the difference in the response of investment to cash flow across constrained and unconstrained subgroups is actually greater, once one controls for the predictive content of cash flow for future profit opportunities. This result is encouraging because it suggests that even if we cannot correctly identify the underlying investment model, by making comparisons across subgroups of firms we are still likely to obtain a reasonably correct answer for the degree of excess sensitivity of constrained firms relative to unconstrained firms. ${ }^{16}$

While the G-H results are informative, it is not clear how robust they are to alternative time frames, data sets, and forecasting rules. The last are particularly important, since G-H rely on a VAR forecast that is

16 It is worth emphasizing that many papers in the literature, including Fazzari, Hubbard, and Petersen (1988), either explicitly or implicitly acknowledge the identification problems posed by using Tobin's $Q$ and are more likely to rely on comparisons across firms rather than focus on the overall cash flow coefficient, when assessing the importance of financial frictions. 
restricted to be common across all manufacturing firms, once they control for fixed firm and time effects. To the extent that such a restriction is invalid, we may not obtain a good proxy for future profit opportunities and may seriously bias the parameter estimates on cash flow.

Gilchrist and Zakrajšek (1995) investigate this point using the quarterly frequency, firm-level QFR data. The application of the VARbased measure of profit opportunities is particularly important for the QFR data set, since many of the firms in the sample are not publicly traded and, therefore, do not have a stock-market-based measure of profit opportunities available. Using the G-H methodology, Gilchrist and Zakrajšek (1995) compare a variety of forecasting rules, including firm-specific, industry-specific (2-digit SIC), sector-specific (durables versus nondurables) as well as aggregate forecasting equations, and find the $\mathrm{G}-\mathrm{H}$ results robust to these alternatives. In fact, of all forecasting systems considered, the G-H restriction that the forecasting equation is common across all firms in manufacturing, after controlling for fixed firm and time effects, provides the smallest residual sensitivity of investment to cash flow for both financially constrained and unconstrained subgroups. In addition, Gilchrist and Zakrajšek (1995) confirm the G-H result that unconstrained subgroups show no excess sensitivity of investment to cash flow, once one controls for cash flow's forecasting power of future profit streams. Nonetheless, a large residual correlation remains between investment and cash flow for constrained subgroups, even after controlling for the predictive power of cash flow for future profit opportunities. In fact, Gilchrist and Zakrajšek (1995) find that the investment of constrained firms is just as responsive to cash flow shocks as it is to future profit opportunities, with an elasticity around 0.12 . This latter finding, combined with the fact that, by their definition, financially constrained firms account for over 30 percent of the capital stock in the economy, strongly suggests that financial frictions are an important determinant of business fixed investment in the manufacturing sector.

The methodology used by Gilchrist and Himmelberg (1994) and Gilchrist and Zakrajšek (1995) follows that of numerous other researchers who start with a well-specified investment equation and then look for departures from this equation that are consistent with a model based on financial frictions. The alternative model under imperfect capital markets is neither specified nor estimated. Therefore, although these exercises are useful in providing evidence against the null hypothesis of perfect capital markets, they do not provide an alternative set of parameter estimates that can be used to identify the decision rule of the financially constrained firm. A major limitation is the difficulty involved in specifying the alternative, since theoretical models incorporating credit frictions are either too simple or too intractable to be tested by empirical data.

Some headway has been made in constructing investmont modals 
with financial frictions that can be tested empirically. One approach is to specify ad hoc, realistic rules that govern a firm's ability to obtain external funds and then solve the model using numerical techniques. Gross (1994) is a recent example of this approach. Not only does Gross (1994) specify the alternative to the perfect capital market case, but he also takes the model to data by estimating the reduced-form of the decision rule using non-parametric methods. While the reduced-form results provide additional evidence in favor of a credit mechanism for firm-level investment, we still do not obtain the underlying parameter estimates that are necessary to fully evaluate the decision rule and, thus, to quantify the overall importance of credit for investment spending. For this type of exercise, we must still rely on reduced-form interpretations of the data.

Identification of capital market frictions using reduced-form equations at the micro level depends on methods similar to those used with time series data. The point is to develop empirical evidence that is consistent with a model based on capital market frictions but would be much more difficult to explain in a world where such frictions were absent. For example, although we would expect cash flow to be an important explanatory variable for investment even in the absence of capital market frictions, this is not so obviously true for inventories, since nearly all structural models of inventory behavior rely on sales rather than profits as the principal determinant of optimal inventory investment. In addition, to the extent that cash flow has greater explanatory power for firms that are likely to be constrained, we have further evidence in favor of a financial markets imperfection story. ${ }^{17}$

This identification scheme is used by Zakrajšek (1994) to measure the importance of financial frictions in the retail sector, using a sample constructed from the firm-level QFR data. The advantage of the data set that provides information on non-publicly traded firms is particularly important for the retail trade, where a much lower proportion of total assets is held by publicly traded firms. The focus on inventory investment in retail trade is motivated by the fact that inventory investment in this sector is the most volatile component of aggregate inventory investment (see Blinder and Maccini 1991). Both the cross-sectional and the time series results from Zakrajšek (1994) are consistent with the presence of a financial accelerator in the retail trade sector. First, cash flow is, both statistically and economically, a significant predictor of inventory investment for firms with "weak" balance sheet conditionsthat is, firms with large debt burdens and no access to the commercial 
paper market. ${ }^{18}$ Second, the predictive power of cash flow for inventory growth of firms with weak balance sheet conditions is highly asymmetric over the course of the business cycle, increasing considerably in recessions relative to normal times.

\section{Some New Results from Firm-Level QFR Data}

While the results of Zakrajšek (1994) are interesting, it is important to examine their robustness across broader sectors of the economy. Accordingly, we apply the identification scheme used in Zakrajšek (1994) to a similarly constructed, firm-level QFR data set for the manufacturing sector. We estimate an inventory regression that includes lags of both inventories and sales in order to capture desired inventory behavior, and lagged cash flow to capture a financial effect. We rank observations based on last period's net leverage ratio and split the data into four quartiles based on this ranking. ${ }^{19}$ The details of the exact econometric specification and data construction are provided in the appendix.

Table 4 provides the first set of estimation results. It compares the response of inventory investment to cash flow shocks across the four subsets of firms, classified by leverage. All four categories show a positive response of inventory investment to cash flow, with the coefficient on cash flow increasing monotonically across the four leverage categories. The monotonic increase in cash flow coefficients is consistent with the view that internal funds are an important determinant of inventory investment for financially constrained firms. Nonetheless, the fact that inventory investment of firms in the lowest quartile of the net leverage distribution responds to cash flow is difficult to interpret, and it highlights the costs of eschewing structural models even as benchmarks. An extreme interpretation would attribute all of the explanatory power of cash flow to the effect of capital market frictions. An alternative interpretation would attribute the explanatory power of cash flow for low net leverage firms to an underlying perfect capital markets model and attribute the differential effect across different quartiles to capital market frictions. Even with this more restrictive

18 Zakrajšek (1994) relies on a "net-leverage" measure of balance sheet conditions proposed by Sharpe (1994) and recently used by Calomiris, Orphanides, and Sharpe (1994).

${ }^{19} \mathrm{It}$ is worth noting that the choice of sample-splitting criterion is also a relevant identification issue. Although we do not explicitly address the issue in this paper, evidence on the importance of financial effects in micro spending equations is robust to a wide variety of sample-splitting methodologies, using both exogenously determined criteria such as size, dividend policy, and ownership structure (see Fazzari, Hubbard, and Petersen (1988), Hoshi, Kashyap, and Scharfstein (1991), Oliner and Rudebusch (1992) and $\mathrm{Ng}$ and Schaller (1993)) and endogenously determined criteria derived from switching regime models (see Hu and Schiantarelli 1994). 
Table 4

The Effect of Cash Flow on Manufacturing Inventory Investment

Dependent Variable: $\Delta \ln N_{i t}$

\begin{tabular}{lcccc}
\hline & Quartile I & Quartile II & Quartile III & Quartile IV \\
\hline $\ln (N / S)_{i}$ & .145 & .124 & .127 & .161 \\
& $(.004)$ & $(.004)$ & $(.004)$ & $(.004)$ \\
$\ln \left(N_{i t-1} / S_{i t}\right)$ & -.144 & -.124 & -.127 & -.169 \\
& $(.003)$ & $(.004)$ & $(.004)$ & $(.004)$ \\
$\Delta \ln N_{i t-1}$ & -.145 & -.085 & -.081 & -.028 \\
& $(.006)$ & $(.006)$ & $(.006)$ & $(.006)$ \\
$\Delta \ln S_{i t-1}$ & -.081 & -.067 & -.072 & -.069 \\
& $(.005)$ & $(.005)$ & $(.005)$ & $(.005)$ \\
$\Pi_{i t-1} / T A_{i t-2}$ & .282 & .396 & .493 & .582 \\
$F^{2}$ & $(.031)$ & $(.027)$ & $(.035)$ & $(.040)$ \\
Observations & .098 & .077 & .074 & .088 \\
& 29,612 & 29,869 & 29,575 & 28,484 \\
\hline
\end{tabular}

Notes: Standard errors in parentheses. All equations included fixed time effects (not reported) and are estimated with OLS. A minimum of 8 quarters and up to 51 quarters of data were used to compute a consistent estimate (the sample mean) of the firm-specific inventory-sales target ratio $(\mathrm{N} / \mathrm{S})_{i}$. The log of this variable is included to control for fixed individual effects. Sample range: 1979:QIII-1991:QIII.

interpretation, we have substantial evidence of excess sensitivity of inventory investment to earnings, for high net leverage firms.

While Table 4 provided information on the average response of inventories to cash flow across the full sample, Table 5 provides information on the cyclicality of the response over the business cycle. We do this by reestimating the inventory equation across two-year subintervals for firms divided into two categories--low and high net leverage. ${ }^{20}$ In Table 5, we report the cash flow coefficient and its standard error for both the low and high net leverage categories in each subsample. We also report the differential response of inventories to cash flow shocks across the two subgroups as well as the associated standard errors. Table 5 clearly shows the cyclical nature of the importance of internal funds for inventory investment. The highest differential responses occur in the 1980-1982 downturn and following the 1989 monetary contraction that preceded the 1990 recession. In these episodes, the differential effect of cash flow on inventory investment is nearly twice as high as in 1985-86, the period with the lowest differential response.

It is worth emphasizing that the findings here come not from small

${ }^{20}$ The low net leverage observations represent the firms with net leverage less than the median value over the two-year estimation period. We use two rather than four classifications for ease of comparison. 
Table 5

The Effect of Cash Flow on Manufacturing Inventory Investment Asymmetric Effects over the Business Cycle

\begin{tabular}{cccc}
\hline Time Period & Unconstrained $^{\mathrm{a}}$ & Constrained $^{\mathrm{b}}$ & Difference $^{c}$ \\
\hline 79:QIII-80:QIV & .384 & .612 & .228 \\
& $(.052)$ & $.065)$ & $(.083)$ \\
81:QI-82:QIV & .320 & .649 & .329 \\
& $(.055)$ & $(.067)$ & $(.087)$ \\
83:QI-84:QIV & .410 & .552 & .142 \\
& $(.055)$ & $(.070)$ & $(.089)$ \\
85:Q1-86:QIV & .395 & .526 & .131 \\
& $(.056)$ & $(.058)$ & $(.081)$ \\
87:QI-88:QIV & .357 & .540 & .183 \\
& $(.051)$ & $(.065)$ & $(.083)$ \\
89:QI-90:QIV & .247 & .564 & .317 \\
& $(.056)$ & $(.076)$ & $(.094)$ \\
\hline
\end{tabular}

Notes: Standard errors in parentheses. All equations included fixed time effects (not reported) and are estimated with OLS. A minimum of 8 quarters and up to 51 quarters of data were used to compute a consistent estimate (the sample mean) of the firm-specific inventory-sales target ratio $(N / S)_{j}$. The log of this variable is included to control for fixed individual effects. Sample range: 1979:QIII-1991: QIV.

a Point estimates on cash flow for firms in Quartiles I and II.

b Point estimates on cash flow for firms in Quartiles III and IV.

c Difference in point estimates on cash flow between constrained and unconstrained firms.

versus large firm comparisons as in Gertler and Gilchrist (1994), but from a sample of firms classified by financial policy. As such, one cannot easily explain away the differences in inventory investment response by attributing them to unmodeled industry or size effects. In addition, besides providing independent support for the idea that the differential inventory behavior between firms documented by Gertler and Gilchrist (1994) is driven by financial factors, this evidence confirms the findings of Kashyap, Lamont, and Stein (1994) on the cyclical nature of credit effects in inventory equations.

While these regressions provide strong micro evidence in support of a financial accelerator for inventory investment, it is important to ask, "Why do these differential effects matter in the aggregate?" Although a complete answer to this question is beyond the scope of this paper, we provide two pieces of evidence to suggest they would indeed matter. We proceed by calculating the share of inventories that would fall into the two quartiles with high net leverage (that is, firms above the 50th percentile of the net leverage distribution). This percentage is plotted in Figure 2. This figure has two noteworthy aspects. First, high net leverage firms account for a significant share of inventories-at least 30 percent. Second and more striking, the share of inventories held by high net leverage firms rises dramatically following tight-money episodes 
Figure 2

\section{The Relative Importance of Financially CONSTRAined FIrMS}

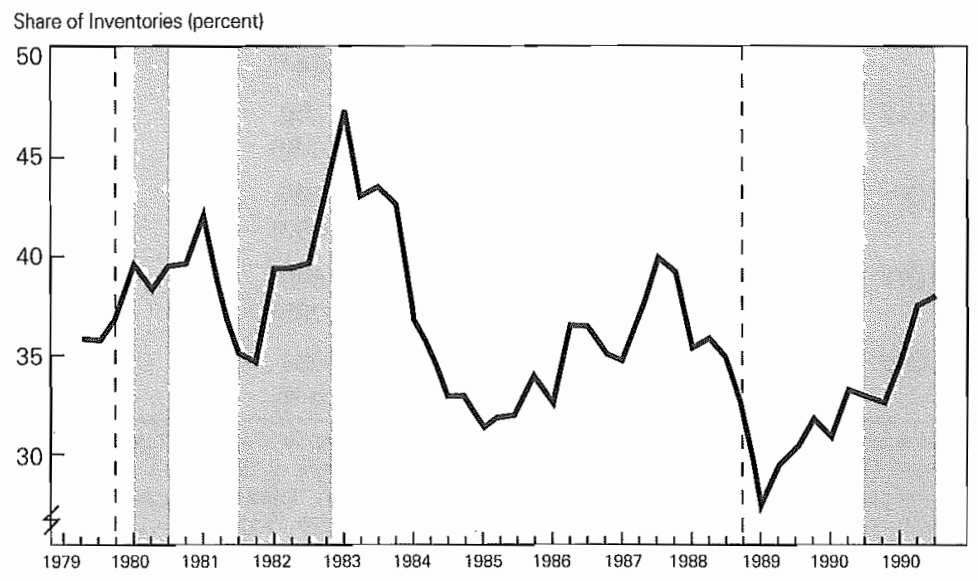

Note: Dashed lines represent Romer dates. The shaded regions represent NBER-dated recessions. Seasonally adjusted data.

and during recessions, with at least a 15 percent increase during the 1981-82 recession and a steady climb after the onset of tight money in 1989 through the 1991 recession. Based on this evidence, it is easy to see how one could obtain asymmetric responses of inventory investment to financial conditions using the aggregate data. As more firms become highly indebted throughout the economic downturn, and as the responsiveness to earnings of highly indebted firms increases throughout the downturn, the amplification effects associated with the financial accelerator become more relevant for aggregate economic activity.

\section{CONCLUSION}

This paper addresses the issues surrounding the identification and quantification of the effects of financial market imperfections on firm behavior. The paper emphasizes the essential role that heterogeneity plays in assessing the importance of credit market frictions, and the need for data sets that accurately reflect such heterogeneity when measuring the relevance of financial frictions. The paper also provides some new empirical evidence using time series data on debt. In 
particular, we find substantial evidence that small-firm versus large-firm borrowing has predictive power for a variety of measures of aggregate economic activity. We also find that monetary policy has a substantial influence over the differential behavior of these debt variables, with a tightening of monetary policy leading to a drop in small-firm debt relative to large-firm debt.

Using firm-level data, we find substantial evidence that inventory investment is highly responsive to the availability of internal funds, for firms that find themselves in weak balance sheet positions. In addition, the percentage of manufacturing inventories held by such firms increases dramatically during economic downturns, making overall inventory investment much more sensitive to balance sheet conditions during such periods of low economic activity. Overall, these results provide substantial support for the view that a credit mechanism plays an important role in conditioning the macroeconomy's response to underlying economic disturbances.

\section{Appendix}

From the certainty component of the firm-level QFR data base, we selected an unbalanced panel of firms from 1979:QI through 1991:QIII. ${ }^{21}$ From this unbalanced panel, we dropped all firms that had tenure of less than 8 quarters or had any discontinuities in their time series record.

- Inventories: The QFR data report the book value of total inventories. Firms in the sample were required to hold strictly positive inventories at each point of their tenure in the panel. In order to eliminate the inflation bias from the inventory growth rate, inventory stocks were deflated by the implicit GNP deflator prior to constructing growth rates. We let $N_{i t}$ denote the real value of inventories of firm $i$ in period $t$.

- Sales: To construct a real measure of sales, the reported nominal value of sales was deflated by the implicit GNP price deflator. As with inventories, firms were required to have strictly positive sales at each point of their tenure in the panel. $\mathrm{We}$ let $S_{i t}$ denote the real value of sales of firm $i$ in period $t$.

- Internal Finance: The measure of internal funds in this paper is defined as cash flow relative to last period's total assets. Cash flow is defined as income (or loss) from operations plus depreciation, depletion, and amortization of property, plant, and equipment. Both cash flow and the book value of total assets are deflated by the implicit GNP price deflator prior to constructing the internal finance ratio. We let $\mathrm{II}_{i t} / T A_{i t-1}$ denote the ratio of real profits of firm $i$ in period $t$ to its real assets in period $t-1$.

- Net Leverage: Financial leverage (the ratio of total debt to total assets) is normally thought of as a measure of a firm's balance sheet condition. A potential problem with identification strategy that classifies firms into "constrained" and "unconstrained" subgroups according to leverage ratio is that total assets consist of a variety of different assets. In particular, a highly liquid component of total assets, in addition to cash stocks, includes time deposits, CDs, and other readily marketable securities that can be quickly and at little cost converted to cash-on-hand

${ }^{21}$ Even though the firm-level QFR data are available from 1977:QI-1991:QIII, we started our sample in 1979:QI, because the 1978:QIV data are missing and we wanted to avoid discontinuities. 
and used to finance inventory investment if internal funds are low and external credit is unavailable; see Kashyap, Lamont, and Stein (1994) for the evidence of this phenomenon during the 1982 recession. A more comprehensive measure of a firm's overall balance sheet condition is, according to Sharpe (1994), the net leverage. The measure of net leverage is constructed by subtracting a firm's net short-term assets from both the numerator and the denominator of a firm's leverage ratio. Net short-term assets consist of cash stock, all short-term investment, and trade receivables, minus trade payables.

- Quartiles: In each period $t$, a firm is assigned to one of four quartiles, based on its $t-1$ period's net leverage. The first quartile contains all firms with net leverage below the 25th percentile; the second quartile contains all firms with net leverage between the 25th and the 50th percentiles; the third quartile contains all firms between the 50th and 75th percentiles; and, finally, the fourth quartile contains all firms with net-leverage above the 75th percentile. We allow the cutoff points (that is, the 25th, 50th, and 75th percentiles) to vary over time by computing them for each year of our sample separately. For example, a firm in 1980:QII is assigned to the first quartile if its net leverage in 1980:QI is less than the 25th percentile of the net leverage distribution computed over all four quarters of the year 1980.

We use the following econometric specification to measure the effect of credit frictions on inventory investment:

$\Delta \ln N_{i t}=\beta_{1} \ln \left(\frac{N}{S}\right)_{i}+\beta_{2} \ln \left(\frac{N_{i t-1}}{S_{i t}}\right)+\beta_{3} \Delta \ln N_{i t-1}+\beta_{4} \Delta \ln S_{i t-1}+\beta_{5}\left(\frac{\Pi_{i t-1}}{T A_{i t-2}}\right)+d_{t}+\epsilon_{i t}$.

The dependent variable is the growth rate of inventories. The first two terms reflect the effect of the deviation of the current $\log$ inventory/sales ratio from its firm-specific target, $\ln (N / S)_{i}$. A consistent estimate of the target inventory/sales ratio for firm $i$ is computed according to

$$
\ln \left(\frac{N}{S}\right)_{i}=\frac{1}{T_{i}} \sum_{i=1}^{T_{i}}\left(\ln N_{i t}-\ln S_{i t}\right)
$$

where $T_{i}$ denotes the number of quarters that firm $i$ is in the sample (a minimum of 8 quarters and a maximum of 51 quarters). The lag of $\Pi_{i t} / T A_{i t-1}$ is meant to capture the effect of financial frictions on inventory investment; the fixed time effect, $d_{t}$, is added to control for aggregate shocks such as overall price movements or interest rate shocks, while lags of $\Delta \ln N_{i t}$ and $\Delta \ln S_{i t}$ are included to capture any additional short-run dynamics.

\section{References}

Attanasio, Orazio P. 1995. "The Intertemporal Allocation of Consumption: Theory and Evidence." Carnegie-Rochester Conference Series on Public Policy, vol. 42, pp. 39-90.

Bernanke, Ben. 1993. "Credit in the Macroeconomy," Federal Reserve Bank of New York Quarterly Review, Spring, pp. 50-70.

Bernanke, Ben and Alan S. Blinder. 1992. "The Federal Funds Rate and the Transmission of Monetary Policy." The American Economic Review, vol. 82, pp. 901-21.

Bernanke, Ben and Mark Gertler. 1989. "Agency Costs, Net Worth, and Business Fluctuations." The American Economic Review, vol. 79, pp. 14-31.

1990. "Financial Fragility and Economic Performance." Quarterly Journal of Economics, vol. 105, pp. 97-114.

1995. "Inside the Black Box: The Credit Channel of Monetary Policy Transmission," Journal of Economic Perspectives, vol. 9, pp. 27-48.

Bernanke, Ben, Mark Gertler, and Simon Gilchrist. 1994. "The Financial Accelerator and the Flight to Quality." National Bureau of Economic Research Working Paper no. 4789 (July). Forthcoming, Review of Economics and Statistics. 
Blinder, Alan S. and Louis J. Maccini. 1991. "Taking Stock: A Critical Assessment of Recent Research on Inventories." Journal of Economic Perspectives, vol. 5, pp. 73-96.

Blundell, Richard, Stephen Bond, Michael Devereux, and Fabio Schiantarelli. 1992. "Investment and Tobin's Q." Journal of Econometrics, vol. 51, pp. 233-57.

Calomiris, Charles W., Charles P. Himmelberg, and Paul Wachtel. 1995. "Commercial Paper, Corporate Finance, and the Business Cycle: A Microeconomic Perspective." Carnegie-Rochester Conference Series on Public Policy, vol. 42, pp. 203-50.

Calomiris, Charles W. and R. Glenn Hubbard. 1990. "Firm Heterogeneity, Internal Finance, and Credit Rationing." Economic Journal, vol. 100, pp. 90-104.

Calomiris, Charles W., Athanasios Orphanides, and Steven A. Sharpe. 1994. "Leverage as a State Variable for Employment, Inventory Accumulation, and Fixed Investment." NBER Working Paper no. 4800.

Carpenter, Robert E., Steven M. Fazzari, and Bruce C. Petersen. 1993. "Inventory (Dis)Investment, Internal Finance Fluctuations, and the Business Cycle." Mimeo, Emory University.

Chirinko, Robert S. and Huntley Schaller. 1993. "Why Does Liquidity Matter in Investment Equations?" Mimeo, Federal Reserve Bank of Kansas City.

Devereux, Michael and Fabio Schiantarelli. 1989. "Investment, Financial Factors, and Cash Flow: Evidence from U.K. Panel Data." In R. Glenn Hubbard, ed., Asymmetric Information, Corporate Finance, and Investment, pp. 279-306. Chicago, IL: The University of Chicago Press.

Fama, Eugene F. 1980. "Banking in the Theory of Finance." Journal of Monetary Economics, vol. 6, pp. 39-57.

Fazzari, Steven M., R. Glenn Hubbard, and Bruce C. Petersen. 1988. "Financing Constraints and Corporate Investment." Brookings Papers on Economic Activity, No. 1, pp. 141-95.

Gale, Douglas and Martin Hellwig. 1985. "Incentive-Compatible Debt Contracts: The One Period Problem." Review of Economic Studies, vol. 52, pp. 647-63.

Gertler, Mark. 1988. "Financial Structure and Aggregate Economic Activity: An Overview." Journal of Money, Credit, and Banking, vol. 20, pp. 559-88.

- 1992. "Financial Capacity and Output Fluctuation in an Economy with MultiPeriod Financial Relationship." Review of Economic Studies, vol. 29, pp. 455-72.

Gertler, Mark and Simon Gilchrist. 1991. "Monetary Policy, Business Cycles and the Behavior of Small Manufacturing Firms." NBER Working Paper no. 3098.

1993. "The Role of Credit Market Imperfections in the Monetary Transmission Mechanism: Arguments and Evidence." Scandinavian Journal of Economics, vol. 95, pp. 43-64.

_- 1994. "Monetary Policy, Business Cycles and the Behavior of Small Manufacturing Firms." Quarterly Journal of Economics, vol. 109, pp. 309-340.

Gilchrist, Simon and Charles P. Himmelberg. 1994. "Evidence on the Role of Cash Flow for Investment." Forthcoming, Journal of Monetary Economics.

Gilchrist, Simon and Egon Zakrajšek. 1995. "Investment and the Present Value of Profits: An Analysis Using Firm-Level Data." Mimeo, Boston University.

Greenwald, Bruce C. and Joseph E. Stiglitz. 1993. "Financial Market Imperfections and Business Cycles." Quarterly Journal of Economics, vol. 108, pp. 77-114.

Gross, David. 1994. "The Investment and Financing Decisions of Liquidity Constrained Firms." Mimeo, Massachusetts Institute of Technology.

Himmelberg, Charles P. and Donald P. Morgan. 1995. "Is Bank Lending Special?" This volume.

Hoshi, Takeo, Anil Kashyap, and David Scharfstein. 1991. "Corporate Structure, Liquidity, and Investment: Evidence from Japanese Industrial Groups." Quarterly Journal of Economics, vol. 106 , pp. 33-60.

$\mathrm{Hu}$, Xiaoqiang and Fabio Schiantarelli. 1994. "Investment and Financing Constraints: A Switching Regression Approach Using U.S. Firm Panel Data." Working Paper No. 284, Department of Economics, Boston College.

Jaffe, Dwight M. and Thomas Russell. 1976. "Imperfect Information, Uncertainty, and Credit Rationing." Quarterly Journal of Economics, vol. 90, pp. 651-66.

Jensen, Michael and William Meckling. 1976. "Theory of the Firm: Managerial Behavior, 
Agency Costs, and Ownership Structure." Journal of Financial Economics, vol. 3, pp. 305-360.

Kashyap, Anil K., Owen A. Lamont, and Jeremy C. Stein. 1994. "Credit Conditions and the Cyclical Behavior of Inventories: A Case Study of the 1981-1982 Recession." Quarterly Journal of Economics, vol. 109, August, pp. 565-92.

Kashyap, Anil K. and Jeremy C. Stein. 1994. "Monetary Policy and Bank Lending," In N. Gregory Mankiw, ed., Monetary Policy, pp. 221-256. Chicago, IL: The University of Chicago Press.

Kashyap, Anil, Jeremy C. Stein, and David W. Wilcox. 1993. "Monetary Policy and Credit Conditions: Evidence from the Composition of External Finance." The American Economic Review, vol. 83, pp. 78-98.

King, Stephen R. 1986. "Monetary Transmission: Through Bank Loans or Bank Liabilities?" Journal of Money, Credit, and Banking, vol. 18, pp. 290-303.

Kiyotaki, Nobuhiro and John H. Moore. 1993. "Credit Cycles." Mimeo, University of Minnesota.

Lang, William and Leonard Nakamura. 1992. "Flight to Quality and Bank Lending." Mimeo, Rutgers University.

Leland, Hayne and David Pyle. 1977. "Informational Asymmetries, Financial Structure, and Financial Intermediation." Journal of Finance, vol. 32, pp. 371-87.

Long, William F. and David J. Ravencraft. 1993. "The Quarterly Financial Report (QFR) Database." Unpublished manuscript, Center for Economic Studies, U.S. Bureau of the Census.

Modigliani, Franco and Merton Miller. 1958. "The Cost of Capital, Corporation Finance, and the Theory of Investment." The American Economic Review, vol. 48, pp. 261-97.

Morgan, Donald P. 1994. "The Lending View of Monetary Policy and Loan Commitments." Mimeo, Federal Reserve Bank of Kansas City.

Myers, Stewart C. and Nicholas S. Majluf. 1984. "Corporate Financing and Investment Decisions When Firms Have Information That Investors Do Not Have." Journal of Financial Economics, vol. 13, pp. 187-221.

$\mathrm{Ng}$, Serena and Huntley Schaller. 1993. "The Risky Spread, Investment, and Monetary Policy Transmission: Evidence on the Role of Asymmetric Information." Mimeo, Carlton University, Ottawa.

Oliner, Stephen and Glenn Rudebusch. 1992. "The Transmission of Monetary Policy to Small and Large Firms." Mimeo, Board of Governors of the Federal Reserve System. . 1994. "Is There a Broad Credit Channel for Monetary Policy?" Mimeo, Board of Governors of the Federal Reserve System.

Ramey, Valerie. 1993. 'Is There a Credit Channel to Monetary Policy?' Mimeo, University of California, San Diego.

Romer, Christina D. and David H. Romer. 1990. "New Evidence on the Monetary Transmission Mechanism." Brookings Papers on Economic Activity, No. 1, pp. 149-213.

Schaller, Huntley. 1993. "Asymmetric Information, Liquidity Constraints, and Canadian Investment." Canadian Journal of Economics, vol. 26, pp. 552-74.

Sharpe, Steven A. 1994. "Financial Market Imperfections, Firm Leverage, and the Cyclicality of Employment." The American Economic Review, vol. 84, pp. 1060-1074.

Stiglitz, Joseph E. and Andrew Weiss. 1981. "Credit Rationing in Markets with Imperfect Information." The American Economic Review, vol. 71, pp. 393-410.

Townsend, Robert M. 1979. "Optimal Contracts and Competitive Markets with Costly State Verification." Journal of Economic Theory, vol. 21, pp. 265-93.

Williamson, Stephen D. 1987. "Costly Monitoring, Loan Contracts, and Equilibrium Credit Rationing." Quarterly Journal of Economics, vol. 102, pp. 135-45.

Zakrajšek, Egon. 1994. "Retail Inventories, Internal Finance, and Aggregate Fluctuations: Evidence from Firm-Level Panel Data." Mimeo, New York University.

. 1995. "Econometric Analysis of Real and Financial Decisions Using Firm-Level Quarterly Financial Report (QFR) Data." Ph.D. dissertation, New York University. 


\title{
Discussion
}

\author{
William C. Brainard*
}

It is a pleasure to discuss Simon Gilchrist and Egon Zakrajšek's stimulating paper on the importance of credit for macroeconomic activity. The authors and others at this conference are to be commended for their efforts to improve our understanding of the role of bank lending in the monetary transmission mechanism and the extent to which market imperfections may be important in shaping that role. I will begin with some general remarks about the dichotomy drawn between the "money" and "credit" views of the transmission mechanism, and then make some specific comments about the authors' analysis and conclusions.

\section{The Money and Credit Views}

At such a conference 30 years ago, the debate might have focused on whether the quantity of money affected expenditure directly or through interest rates. In the current discussion, the "money view" has been identified as the view that monetary policy works through its effect on the cost of capital, rather than through credit. The view of the cost of capital itself could be quite narrow, limited to a single or limited number of market interest rates, or it could be quite broad, reflecting the prices and rates of return on a wide spectrum of assets and liabilities and stretching all the way to equities and the market value of firms.

Many monetary economists, for example, Brunner-Meltzer and Tobin-Brainard, recognizing the wide spectrum of financial assets and institutions in our highly developed economy, have long taken the

${ }^{*}$ Arthur M. Okun Professor of Economics, Yale University. 
broad view of the cost of capital. This view is entirely consistent with asset demands and supply of credit by bank and nonbank intermediaries playing an important role in the transmission of monetary policy. In this view, the markets for "credit" and monetary assets are highly interdependent, with financial intermediaries, households, and firms interacting in many markets. Hence, it suggests that the magnitude of the response to monetary policy of interest rates and broader measures of the cost to capital such as Tobin's $q$ is importantly affected by the behavior of a broad array of financial markets and institutions. So the broad "money" view is quite different from the stylized picture that has become popular in the money versus credit debate, in which there is clear separation between the two channels-a money channel that goes from money directly to the cost of capital, and a credit channel that traces the effect through the asset side of banks and other intermediaries. As might be expected, I am not a fan of this dichotomy and prefer to analyze the transmission of monetary policy in a general equilibrium model in which the interdependencies of markets are explicitly recognized.

The current "credit view" stresses still another aspect of financial markets and the transmission mechanism, the presence of imperfections in credit and capital markets reflecting significant costs of gathering information and monitoring. Recent theoretical work has formalized and clarified the difficulties for financial markets implied by the presence of asymmetric information and moral hazard. Such phenomena have long been recognized and included in the catalog of reasons for credit rationing, collateral requirements, and other terms and conditions in financial contracts, and indeed for the existence of specialized financial intermediaries themselves. When Franco Modigliani attempted to capture the monetary transmission mechanism in the early versions of the MPS model many years ago, it seemed essential to include quantities of deposit and credit flows. Market interest rates and the rates on mortgages and commercial loans did not appear to capture adequately the effect of monetary events on economic activity. I applaud the resurgence of interest in these phenomena and in the more rigorous analysis of their theoretical foundations, but I find it somewhat ironic that this attention comes at a time when one might suspect that their quantitative importance has declined.

Market imperfections are a matter of degree: The markets for many commodities are imperfect and the textbook model of perfect competition is a caricature of reality, but we do not usually argue that such imperfections negate the central role we attribute to prices in allocating resources. At a formal level, these imperfections, which may drive a wedge between the shadow price (or rate of return) on internal funds and external rates, can be explicitly modeled in an equilibrium model of financial markets. For many of the issues raised at this conference, however, I do not think that it is a gross error simply to regard 
information asymmetries and moral hazard as among the many reasons it is important to treat the assets and liabilities of firms and various intermediaries as less than perfect substitutes. In the equilibrium system of James Tobin, however, distinguishing between "low-quality" and "high-quality" firms does require disaggregation of firms, distinguishing the required rates of return or Tobin's $q$ for different types of firms.

\section{InNovation and THe Effectiveness of Policy}

One issue discussed at this conference can be addressed in this framework without modification. This is whether the growth of nonbanking intermediaries and financial innovations-new financial instruments and financial markets-destroys the effectiveness of a monetary policy that focuses on the reserves of a single intermediary, banks. Multi-asset equilibrium models show that for a wide range of substitutabilities among various assets and liabilities, monetary policy remains effective. Innovations may change the bang per buck, but as long as the dose of medicine can be adjusted for its effectiveness, this is not by itself reason for alarm. But the same innovations that decrease the expected bang per buck may also reduce the predictability of the effect of policy actions, or even increase the magnitude of the shocks with which monetary policy has to cope. So this analysis left many of us concerned about potential loss of monetary control. But so far the loss of control has not materialized. It is not even clear that monetary policy is less effective, requiring more vigorous actions by the monetary authorities to have the same effects. While it is always possible that with even greater proliferation of competitors for banks, and new substitutes for their assets and liabilities, policy effectiveness will suffer, I do not think we have immediate cause for alarm.

One of the predictions of these models does appear to have come true. These models always predicted that the relationship between output and the quantities of any particular notion of money was likely to be unreliable. Indeed, one feature of such models is that the quantities of particular near moneys or financial assets might even move opposite to the direction of narrowly defined money. So while financial innovations do not appear to have become a major problem for the conduct of monetary policy focusing on interest rates and user costs, they have perhaps fatally wounded monetary aggregate targets as a guide to policy.

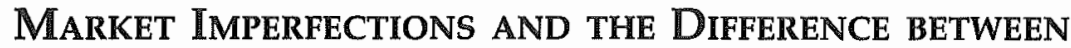 INTERNAL AND EXTERnAL FINANCE}

Although I am not a fan of the dichotomy between the money and credit views emphasized in much recent literature, I am a fan of the efforts to understand better the role of financial market imperfections in 
the transmission of policy. We do not live in an Arrow-Debreu world, or even a Modigliani-Miller world, in which a separation exists between the financial structure of a firm and its investment decisions. Asymmetric information and moral hazard, stressed by the authors and by much of the recent literature, are almost surely reasons for a wedge between the cost of internal and external funds. This literature tends to stress the need to compensate lenders for the cost of gathering information and monitoring, and for the risks and losses reflecting moral hazard that remain even after incurring those costs. Hence the premium shows up on the supply side, as in Gilchrist and Zakrajšek's Figure 1.

It is interesting to note that Meyer and Kuh, in their classic work The Investment Decision, stress the other side of the market in arguing that a wedge exists between the internal and external costs of capital. They emphasize reasons why the borrowers, managers, and entrepreneurs impute a higher cost to external than to internal funds. Arguing that in the modern firm there is a substantial separation of ownership and control, they give a long list of reasons for a preference for internal finance: bankruptcy and loss of their job, dilution of control, imposition by creditors of covenants and restrictions on their behavior, a minor share in equity returns. These reasons for a wedge are in the same spirit as, and complementary to, the reasons emphasized by the authors of the paper under discussion. I wish we knew more about the magnitude of both of these sources of market imperfection. My own guess is that the sources stressed by Meyer and Kuh are even more important than those emphasized by Gilchrist and Zakrajšek.

It would be very instructive, but probably quite difficult, to obtain quantitative measures of the magnitude of the wedge and of its sources on each side of the market. It is probably easier to get measures of the lender's premium because the lender's costs are more readily identified and because data on the lending of financial institutions are more readily available than the information required to estimate the borrower's premium. To my knowledge, remarkably little work of this sort has been done since the early work by Don Hester which investigated "the commercial loan offer function" and attempted to determine how the terms and conditions of bank loans, and their profitability, depend upon the characteristics of the borrowers. I hope such studies will be on the agenda for future research.

One could believe that a wedge is present between the costs of internal and external funds for the typical firm but not believe in the "financial accelerator," which creates a systematic variation in the wedge over the cycle or with the tightness of monetary policy. However difficult it is to get a precise estimate of the magnitude of the average wedge, it is going to be even more so to get at the more subtle question of its cyclical variation. My own guess is that much of the time, and for many cycles, the financial accelerator is relatively unimportant, but that 
in episodes like the recent New England experience, the accelerator is at work in an important way. The lesson is not to assume that what you see every day is what you are going to see in the extreme; and monetary authorities are well advised to worry about the increased sensitivity of response to their actions in circumstances where unusually large numbers of firms have unusually high leverage or low coverage.

\section{Testing the Usefulness of Credit Flows IN PREDICTING ECONOMIC ACTIVITY}

One way to test for the presence of financial market imperfections is to examine the value of the borrowing rates of "low-quality" firms relative to "high-quality" firms in predicting aggregate variables. The authors report four sets of vector autoregressions testing the usefulness of such variables in forecasting economic activity. They find that in bivariate regressions relating various debt measures to GNP, industrial production, inventories, and employment, the ratio of the short-term debt of small manufacturing firms to that of all manufacturing firms does well. In their words, the results provide "strong support for the hypothesis that credit flows between small and large firms predict real economic activity." However, as the authors note, there is an awkwardness, in that the predictive power of this variable is captured almost entirely by the quantity of large-firm, short-term debt; large-firm debt is significantly and negatively related to economic activity. Small-firm debt has a positive but insignificant effect.

The authors downplay this result, noting that the predictive power of the small/all mix remains when other variables, including the federal funds rate and inflation, are included. They also note that with the inclusion of such variables, the predictive power of large-firm debt variables is diminished. In these multivariate VARs, the only case where large-firm debt by itself is even marginally significant is the case of inventories. In these multivariate regressions, I am puzzled by the difference in results for the exclusion tests and for the tests on the sum of coefficients. For example, the sum of coefficients for large-firm, short-term debt is significant for both industrial production and employment, but not for inventories, whereas according to the exclusion tests it is most significant for inventories. Of course this result is logically possible, but with the number of degrees of freedom it seems somewhat surprising. The sensitivity of results to the precise specification is disconcerting and suggests that the power of the tests is low; in any case, it may be desirable to downplay the significance of the bivariate results. The authors also note that, contrary to the suggestion of the theory, the ratio of bank loans to bank loans plus commercial paper does not do too well-it is only marginally significant in the bivariate regressions. 
How are we to interpret the success of the ratio of small-firm to all-firm debt in predicting economic activity, particularly when smallfirm debt by itself does not to appear to play a particularly important role? One possibility is that it simply reflects the nonlinear treatment of large-firm debt, which does so well in the bivariate regressions and which enters in the denominator in these regressions. Another possibility is that small-firm and large-firm debt move together much of the time, but that during downturns or credit crunches, something special happens that is picked up by the ratio. Possibly the variable is a proxy for a subsample of the period that is particularly important for the results-for example, the highly inflationary period at the end of the 1970s and the tight money period that followed. This suggests, together with the significant changes in institutions, regulations, and market instruments over the sample period, the desirability of testing for the stability of the relationships over time. In the same spirit, the presumption that a firm's financial conditions are nonlinearly related to borrowing premiums suggests examining special episodes-credit crunches or periods of widespread financial stress-where these effects would be largest. While the authors do not report such tests for the VARs, they do follow this strategy when they explore the effect of cash flow on inventories.

Just as it is interesting to know what we can infer about future economic activity from the debt variables, it is desirable to have some sense of the proximate determinants of the debt variables themselves. The authors provide a set of VARs that include the debt variables, the federal funds rate, and, in some cases, industrial production. In the bivariate VARs the federal funds rate appears to have a significant effect on small-firm and large-firm bank and other debt, as well as on the small/all mix. However, the significance of the federal funds rate is reduced when industrial production is included, suggesting that much of this effect is indirect; it appears that economic activity, which could be affecting either the demand for or the supply of credit, is the major determinant of the debt variables.

The authors also exploit the firm-level QFR data to examine the sensitivity of inventory investment to cash flow, controlling for sales and a firm-specific inventory/sales ratio. Classifying firms into four categories by leverage, they find that the higher the leverage, the larger the effect of cash flow on inventory holdings, suggesting highly levered firms have a larger external finance premium. The use of firm data also provides the degrees of freedom to enable them to estimate the importance of cash flow for two-year subperiods. An interesting and suggestive finding is that the differential response for low- and highleverage firms, always in the expected direction and frequently significant, is most dramatic in the 1980-82 downturn and following the monetary contraction in 1989 . The authors calculate that the share of 
inventories that falls into the high-leverage category not only is significant but rises dramatically following tight-money episodes and during recessions. These results suggest that the credit effects are not only significant in the aggregate but likely to become even more important in sustained downturns.

In closing, I would like to congratulate the authors for producing an interesting and stimulating paper. It is an excellent model of how to use firm-level data to shed light on the behavior of the aggregate economy and on the interplay between financial and real activity. Yet much remains to be done, and I look forward to the next installments. 


\section{DISCUSSION}

\section{Stephen D. Oliner*}

Over the past few years, the team of Mark Gertler, Simon Gilchrist, and Egon Zakrajšek has produced important research on the transmission of monetary policy. Their work has highlighted the differential effect of policy actions on small and large firms, based on a careful analysis of data presented in the Census Bureau's Quarterly Financial Report for Manufacturing, Mining and Trade Corporations, the so-called QFR data. This experience makes Gilchrist and Zakrajšek eminently qualified to write the paper for this session of the conference.

The core of their paper is a progress report on research using the QFR data. Most of the results will be familiar to readers who have followed this literature, but the authors also present several new findings. The results, they argue, provide compelling evidence in favor of an important credit channel for monetary policy, especially one that operates beyond the confines of the banking sector. I agree with most of the points in the paper. In particular, I am persuaded that a credit channel does exist and that bank loans are not the sole vehicle for this channel. However, in my view, the research to date has yet to establish that the credit channel is a consistently important part of the transmission mechanism. Much further research is needed, both to determine the aggregate importance of the credit channel and to expand our still incomplete understanding of the differential effects of monetary policy.

Before turning to more specific comments, it may be helpful to

*Chief, Capital Markets Section, Division of Research and Statistics, Board of Governors of the Federal Reserve System. The author thanks Steven Sharpe for helpful suggestions on an earlier draft. The opinions expressed herein are those of the author alone and should not be attributed to the Board of Governors of the Federal Reserve System or its staff. 
clarify some terminology concerning a credit channel for monetary policy. The paper correctly distinguishes two possible forms of the credit channel. In the first, which the authors call simply the "credit channel," policy actions affect the supply of loans from commercial banks and other depositories and, in turn, the real spending of borrowers with limited access to nonbank funding. Because this channel ascribes a special role to banks, I will refer to it as the "bank credit channel," eschewing the less precise term used in the paper. The second possible form of a credit channel emphasizes capital market imperfections that have nothing to do with banks per se. That is, owing to information asymmetries, some borrowers must pay a premium to obtain external finance. Monetary contractions can magnify this premium by worsening the balance sheets of such borrowers. The authors call this mechanism the "financial accelerator." However, to draw a sharper contrast with the transmission channel that stresses the role of banks, I will term this mechanism the "broad credit channel."

\section{Review and Evaluation of Main Results}

The paper begins by arguing that aggregate data are useless for assessing the existence or importance of either version of the credit channel. This point is surely correct and indeed has become the conventional wisdom in recent years. The basic problem is that aggregate data cannot distinguish shifts in loan supply from shifts in loan demand. Evidence thai both output and borrowing drop after a monetary contraction does not identify whether the decline in loan volume reflects a constriction of loan supply or a dampening of loan demand through the traditional interest rate mechanism. Given this severe identification problem, researchers have focused on the behavioral differences across firms to test for a credit channel. All the QFR research reported in the paper follows this testing strategy.

As noted in the introduction, the paper builds a strong case for the existence of a credit channel. The authors present several lines of evidence to make this case, relying mostly on results obtained from research with the QFR data. I will briefly review the principal conclusions to be drawn from this research.

The first conclusion is that monetary policy actions have a much stronger effect on small firms than on large firms. This was clearly established in Gertler and Gilchrist (1994), who used QFR data for the manufacturing sector to examine the effects of monetary contractions. After a shift to tight money, they find that sales, inventories, and short-term debt all contract at small firms relative to large firms. A skeptic could argue that these differences reflect unequal shifts in demand faced by small and large firms, rather than the operation of a credit channel. However, Bernanke, Gertler, and Gilchrist (1994) show that the relative contraction 
of small firms persists after controlling for differences in the industry mix of the two groups.

Moreover, considerable evidence suggests that a credit channel of some type operates for small firms. The first strand of evidence concerns the behavior of the inventory-sales ratio and the ratio of short-term debt to sales across small and large firms. As shown in Gertler and Gilchrist (1994), both ratios rise at large manufacturing firms after a monetary contraction, as these firms apparently borrow to finance an unexpected inventory accumulation and, more generally, to smooth through an unanticipated drop in cash flow. In contrast, these ratios increase little if at all for small firms, suggesting that they have limited access to the credit needed to perform this smoothing. The second strand is the large body of work that documents the "excess" sensitivity of inventory accumulation and fixed investment of small firms to balance sheet conditions. The paper discusses much of this work-especially that based on QFR data-and adds several new results that bolster the conclusions of the existing literature. This research implies that monetary policy operates, in part, through a credit channel for small firms by affecting the health of their balance sheets and hence their access to credit.

Although the precise form of this credit channel is still open to debate, the QFR research to date is more consistent with a broad credit channel than with one that operates exclusively through the banking sector. As shown in Gertler and Gilchrist (1993), Oliner and Rudebusch (1995a, b), and the current paper, monetary contractions since the mid-1970s have prompted a general reallocation of credit toward large firms but not a significant shift in the mix of bank and nonbank debt for either small or large firms. If monetary policy operated strictly through a bank credit channel, we would expect to observe a decline in bank loans relative to nonbank debt for at least some firms. The absence of such a shift in mix argues against the bank version of the credit channel. At the same time, the widespread diversion of credit away from small firms provides support for the broad credit channel, which stresses the information asymmetries faced by all lenders. That is, a move to tighter monetary policy tends to worsen balance sheet conditions. In that environment, firms that present severe information problems-notably, small firms will find that all forms of credit become less available, consistent with the QFR results.

The authors argue not only that a credit channel exists but also that it represents an important part of the monetary transmission mechanism. They present two pieces of evidence to support this assertion. First, they show that reallocations of credit toward large firms are strongly associated with a subsequent weakening of aggregate activity. Second, they note that the firms found to be credit-constrained in various QFR studies account for a sizable part of the manufacturing 
sector-roughly one-third of the sector's sales, inventories, and capital stock.

Although I do not dispute these points, neither one establishes that the credit channel is important. The basic problem is that actions by unconstrained firms may offset the adverse effects of monetary policy on firms that face financial constraints. For example, assume that the Fed tightens monetary policy, reducing demand for automobiles through the standard interest rate channel. In response, General Motors cancels an order for auto parts with one of its small suppliers. This supplier, already financially shaky, cannot obtain credit to offset the lost revenue and has to shut down. However, if a larger, healthy competitor can step in immediately and fill the firm's remaining orders with no rise in price, the net effect of the credit channel would be zero. If this scenario were repeated throughout the economy, the data would show a significant redistribution of sales from small to large firms. Yet the decline in aggregate activity would be unrelated to the credit channel. Although this example is admittedly extreme, it illustrates a key point: The evidence in the paper shows only that the credit channel is potentially important, not that it is important. No convincing case for the importance of the credit channel can be made until much more is known about the strategic reactions of firms to the financial distress of their competitors.

\section{Areas for Further Research}

Overall, the QFR research has yielded some valuable stylized facts: (1) that small firms bear a disproportionate hit from monetary contractions, due at least in part to the operation of a credit channel, and (2) that the credit channel does not appear to be confined to bank lending. However, our understanding of the microeconomic mechanisms behind these stylized facts is still seriously incomplete. The remainder of my remarks will identify areas in which I see a high payoff from further research.

\section{Behavior of Nonbank Financial Institutions}

To determine whether banks play a special role in the transmission of monetary policy, we need to better understand the response of nonbank financial institutions, principally finance and insurance companies, to policy actions. Such information would provide a benchmark against which to evaluate the lending behavior of banks.

As discussed earlier, the QFR data show that monetary contractions over the past 20 years have not significantly altered the mix of debt for either small firms or large firms. This finding suggests that banks, as a rule, have not tightened credit supply to a greater degree than nonbank 
lenders. However, this result is based on the published QFR data, which disaggregate total manufacturing only into broad size classes. An obvious next step would be to repeat this analysis using the underlying firm-level QFR data, which the authors could do rather easily. This would indicate whether the limited disaggregation in the published QFR data has masked interesting movements in the debt mix for individual firms.

While that exercise would be useful, we must move beyond the QFR data to fully understand the lending behavior of nonbank financial institutions. Both the published QFR data and the underlying micro data lump together all forms of nonbank debt other than commercial paper. As a result, one cannot discern anything about the relative movements of publicly issued bonds, loans and leases from finance companies, private placements of debt with insurance companies and other investors, and loans from family members, friends, and other nonfinancial businesses.

Two projects now under way at the Federal Reserve may eventually shed light on the lending behavior of nonbank financial institutions relative to banks after monetary shocks. Carey, Post, and Sharpe (1995) have begun to analyze a large data set of business loans extended by banks and finance companies to publicly traded firms, the terms of which have been disclosed in filings to the Securities and Exchange Commission. Their results, though still quite preliminary, clearly show that the finance companies lend, on average, to firms with weaker balance sheets than do banks. At the same time, they find little difference across the bank and finance company borrowers with regard to variables often viewed as proxies for the degree of information asymmetry-the ratio of $R \& D$ to sales, the ratio of market to book value, the growth of sales, and firm size. These results indicate that banks have no monopoly on lending to information problematic borrowers. Consequently, one might expect their data to show that banks and finance companies respond in a roughly similar manner to a tightening of monetary policy.

The second project involves the analysis of data collected by the 1993 National Survey of Small Business Finances, which was cosponsored by the Federal Reserve Board and the Small Business Administration. This is the second wave of the Small Business Survey; the first was conducted in the late 1980s. Both waves collected a wealth of data on the characteristics of small businesses and their use of financial services. (See Cole and Wolken (1995) on the 1993 survey, and Elliehausen and Wolken (1990) on the earlier survey.) The 1993 survey will be especially valuable for comparing the behavior of banks and other intermediaries, as it obtained information about each firm's most recent experience applying for credit, including applications that were denied. Although a public-use data tape is not yet available, Federal Reserve 
staff have begun to analyze the 1993 survey data, and I would expect to see interesting results in the near future.

\section{Trade Credit}

The role of trade credit in the monetary transmission mechanism is a second area worthy of further research. Going back at least to Meltzer (1960), some observers have argued that the extension of trade credit can offset tighter loan supply at banks and other intermediaries, shortcircuiting any credit channel. That is, firms with large cash holdings or free access to credit markets can, in effect, provide credit to constrained firms by allowing slower payment for purchased goods. Typically, this trade credit is believed to flow from large firms to small firms.

The analysis to date with QFR data, however, does not support the operation of this mechanism. Both Gertler and Gilchrist (1993) and Oliner and Rudebusch (1995a) examined the movements in trade payables for small manufacturing firms. After monetary contractions, Oliner and Rudebusch found that small-firm trade payables declined about in proportion with their other short-term debt, while Gertler and Gilchrist found that trade payables actually fell as a share of such debt. Although these results cast doubt on the Meltzer story, they are based on the publicly available QFR data and thus do not indicate what is happening for individual firms. It would useful to repeat this analysis with the micro QFR data, which would show whether trade credit functions as a substitute for other debt for certain types of small firms-especially those with sharply deteriorating balance sheets. Case studies likely would be of value as well. A case study could identify each of the firm's suppliers, enabling one to examine the behavior of trade credit with each individually. This level of detail is needed to reconcile the available QFR results with the notion that trade credit provides a buffer against shortfalls in loan supply.

\section{Heterogeneity of Small Firms}

The QFR research to date has treated small firms as a homogeneous group, showing that these firms behave differently than large firms. This approach ignores the interesting differences within the population of small firms. Notably, the dependence of small firms on bank loans varies widely by firm size. For firms with fewer than 10 employees, the 1993 Small Business Survey found that only about one-third obtained any credit at all from commercial banks. These firms often lack the track record and collateral required to obtain loans. In contrast, more than three-quarters of firms with 100 to 499 employees had outstanding bank loans. This pattern suggests that a bank credit channel would be less relevant for the smallest firms in the economy than for those slightly 
further up the size distribution. ${ }^{2}$ Further study of this issue would enhance our knowledge of the differential effects of monetary policy.

Related to this point, we need to better understand the effect of banking relationships on credit availability for small firms. This conference has stressed the importance of these relationships, and rightly so. From the bank's perspective, an ongoing relationship has value because it generates inside information about the firm that can yield monopoly rents. Ending the relationship can be costly because the bank gives up its monopoly power. Thus, banks must make hard decisions when rationing credit after a monetary tightening, and one might expect a long-standing relationship to mitigate any restriction of loan supply. Deeper knowledge about the operation of a credit channel requires that we investigate who gets rationed and why.

\section{CONCLUSION}

The authors should be commended for writing a useful summary of the research on the differential effects of monetary policy on small and large firms. They provide strong evidence that small firms contract relatively sharply after a shift to tight monetary policy and that this difference reflects, at least in part, the existence of a credit channel. In addition, any such credit channel does not appear to operate exclusively through the banking sector. However, the paper does not provide a persuasive answer to the central issue of this conference-namely, "Is bank lending important for the transmission of monetary policy?" This is not a failing of the paper per se. Rather, the profession has yet to establish that any credit channel accounts for much of the real effect of policy actions, much less a credit channel that focuses on the role of bank lending. My comments have outlined some avenues for fruitful research, and clearly much work remains to be done.

\footnotetext{
${ }^{2}$ Of course, the broad credit channel remains quite relevant for the smallest firms. Given their limited access to bank loans and other types of credit, these firms are less able to smooth through shocks to cash flow than are firms that face a smaller premium for external funds.
} 


\section{References}

Bernanke, Ben, Mark Gertler, and Simon Gilchrist. 1994. "The Financial Accelerator and the Flight to Quality." National Bureau of Economic Research Working Paper No. 4789 (July). Forthcoming, The Review of Economics and Statistics.

Carey, Mark, Mitchell Post, and Steven Sharpe. 1995. "Does Lending by Banks and Finance Companies Differ?" Mimeo, Board of Governors of the Federal Reserve System.

Cole, Rebel A. and John D. Wolken. 1995. "Financial Services Used by Small Businesses: Evidence from the 1993 National Survey of Small Business Finances." Federal Reserve Bulletin, vol. 81 (July), pp. 629-67.

Elliehausen, Gregory E. and John D. Wolken. 1990. "Banking Markets and the Use of Financial Services by Small and Medium-Sized Businesses." Federal Reserve Bulletin, vol. 76 (October), pp. 801-17.

Gertler, Mark and Simon Gilchrist. 1993. "The Role of Credit Market Imperfections in the Monetary Transmission Mechanism: Arguments and Evidence." Scandinavian Journal of Economics, vol. 95, pp. 43-64.

1994. "Monetary Policy, Business Cycles and the Behavior of Small Manufacturing Firms." Quarterly Journal of Economics, vol. 109 (May), pp. 309-40.

Meltzer, Allan H. 1960. "Mercantile Credit, Monetary Policy, and Size of Firms." The Review of Economics and Statistics, vol. 42 (November), pp. 429-37.

Oliner, Stephen D. and Glenn D. Rudebusch. 1995a. "Is There a Bank Lending Channel for Monetary Policy?" Federal Reserve Bank of San Francisco Economic Review, no. 2, pp. 3-20.

. 1995b. "A Comment on 'Monetary Policy and Credit Conditions: Evidence from the Composition of External Finance." "Forthcoming in The American Economic Review. 